\title{
An Analysis of the Quantitative and Qualitative Composition of the Nematode Populations in Pineapple Fields in Puerto Rico ${ }^{1}$
}

\author{
Alejandro Ayala ${ }^{2}$ \\ INTRODUCTION
}

Preliminary investigations have shown the presence of large populations of root parasitic nematodes in the pineapple fields of Puerto Rico. A study was undertaken during the months of March through September of 1957 to determine more exactly the size and composition of these populations, the distribution of the various genera, and particularly their relationship to the growth of the pineapple plants. In this study different ecological factors such as the $\mathrm{pH}$ of the soil, texture of the soil, moisture content in relation to the rainfall, temperature, variety of the pineapple, age of the plantation, previous crops planted in the respective fields, and the localitv. were all taken into consideration.

Nematodes were not reported to be attacking pineapple plantings until the beginning of the twentieth century. Most of the work in this field has been done in Hawaii. In 1928 Godfrey $(15)^{3}$ gave a list of legumes resistant to root-knot nematodes. This list is useful in the application of rotation and trap crops for the control of nematodes in Hawaiian pineapple fields. Godfrey and Morita (24) reported on environmental factors which affect the root-knot nematode on pineapple and other crops in Hawaii. He (16) also described a new nematode disease, which affects the pineapple roots and is caused by what was known as Tylenchus brachyurus. Hagan and Collins (28) reported the results of certain experiments on the resistance of some varieties of pineapple to the root-knot nematode which at that time was known as Heterodera marioni (Cornu) Goodey.

The year 1933 was particularly fruitful in regard to studies and publica-

${ }^{1}$ A dissertation submitted to the faculty of the Graduate School of Arts and Sciences of The Catholic University of America, Washington, D.C., in partial fulfillment of the requirements for the degree of Master of Science.

2 Research Assistant Nematologist I, Department of Entomology, Agricultural Experiment Station of the University of Puerto Rico, Río Piedras, P.R. The author wishes to express his gratitude to Drs. Merritt P. Sarles and Herbert C. Hanson for helpful suggestions. To Dr. G. Steiner and Mr. J. Román I extend my grateful appreciation for their aid in the study and collection of data; I wish also to extend my appreciation to all members of the Department of Entomology of the Agricultural Experiment station and to others, who helped generously in the preparation of this paper.

3 Italic numbers in parentheses refer to Literature Cited, pp. 297-9. 
tions on the ecology of the root-knot nematode in pineapple roots. Several papers were published: One on the general environmental relationships of the root-knot nematode, Heterodera radicicola (22); four on the relation of temperature and moisture to the reduction of the number of nematodes (22, 25, 27, 29). Then, in 1934, Godfrey (17) published the results of studies with indicator plants as means for measuring soil populations of the rootknot nematode. In the same year Godfrey and Hagan (20) and Godfrey and Hoshino (28) reported the use of trap crops to reduce root-knot nematode infestation in pineapple fields. Eventually Godfrey (18) summarized the damage done by the root-knot nematode to pineapple root systems. The same investigator, in cooperation with Hagan (21), gave an account of the detrimental effects of the root-knot nematode on pineapple plants. Linford (33) reported on the activity of natural enemies of nematodes; in his experiments pineapple material was used.

In 1935 the reniform nematode, Rotylenchulus reniformis, was observed for the first time on cowpea roots grown in pineapple fields, and a few days later it was found on pineapple roots by Linford and Oliveira (35). Linford and Yap (36) included the pineapple among a list of plants susceptible to attack by reniform nematodes. Linford, Oliveira, and Ishii (87) described a new species, Paratylenchus minutus, and later found that it was the most abundant in old pineapple fields on the Island of Ashec, Hawaiian Archipelago. They concluded that the pineapple plants constituted an excellent habitat for them, while few individuals were found in adjacent grasslands. Linford, in 1952 (34), reported the presence of various nematode species in pineapple fields in Loma Bonita, Mexico; he found that the root-knot nematode (Meloidogyne spp.) and the meadow nematode (Pratylenchus spp.) were causing considerable damage; at the same time Rotylenchus (later divided by G. Steiner into Rotylenchus and Helicotylenchus), was also abundant. Some other papers have been published on the ecology of parasitic nematodes in the pineapple; however, a complete list of these is not available at this time.

Until recently studies like the ones here listed have not been made in Puerto Rico. The first report on nematodes attacking pineapple plants on the Island was made by Pennock (41), who observed that the root-knot nematode at that time known as Heterodera marioni, was causing disease to pineapple plants, but concluded that this did not represent any threat to the production of pineapple in Puerto Rico. In the Annual Report of the Agricultural Experiment Station for 1952-53 (30), nematodes were mentioned together with white grubs and mealybugs as being one of the causes of the characteristic degeneration of the Red Spanish variety of pineapples on the Island. Alvarez and López (I) gave an account of the reduction in 
plant vigor of the Red Spanish variety of pineapple in Puerto Rico caused by the root-knot nematode. They reported the results of several controlled tests of nematodes conducted in different parts of the Island. Furthermore, in the Annual Report of the Agricultural Experiment Station for 1953-54 (31), mention was also made of nematodes being one of the causes of the decline in pineapple production. Pérez (42) included the nematodes as one of the principal plagues of pineapple fields. Thus damage caused by nematodes in different pineapple fields of Puerto Rico had been reported; however no close study of the situation had been attempted.

In previous years the author and other members of the Department of Entomology of the Agricultural Experiment Station have received numerous samples of soil and roots from pineapple fields suspected to be infected with nematodes, and indeed, laboratory examinations proved that large numbers of nematodes were present in and on these roots. It was presumed that they caused great damage and extensive losses. Observations made in the field revealed that the disease symptoms present in many places were similar to those reported from other pineapple areas such as those of Hawaii.

Further to advance the study and control of these nematodes a study of the distribution of populations, their composition, and their bionomics was deemed desirable. To this end a project was undertaken in which three of the four pineapple areas on the Island were studied. In the present paper the results of that study will be discussed in detail, taking into consideration the different ecological factors. The main purpose of the study was to demonstrate the relationship of populations to damage as observed under different ecological factors and to show the need for further work.

\section{MATERIALS AND METHODS}

The pineapple areas in Puerto Rico comprise four main regions, e.g. the Northern, the Southwestern, the Central, and the Vieques Regions, but only the first three were studied. Compound samples were taken at random from 60 different plantings, some of which showed the characteristic symptoms of nematode disease while others did not. The method for sampling the fields was a modification of that described by. Cobb (11), insofar as a spade was used instead of Cobb's sampling tubes, and special paper bags were used instead of plastic bags. Each compound sample comprised from 20 to 30 subsamples taken at the 15- to $20-\mathrm{cm}$. depth in an even distribution across the selected fields. These samples were then thoroughly mixed in the laboratory and $300 \mathrm{cc}$. of soil processed. A combination of the sieving method of Cobb (11) and the Baermann-funnel method (12), as described by Christie and Perry $(6)$, was used, with a few modifications, to extract and concen- 
trate the nematodes. Standard sieves of 25,50 , and 325 meshes to the inch were used. The extracted nematodes were examined under the microscope after 24 and 48 hours, using 5- to 6-percent formalin solution as a preservative. Slides were prepared from the samples kept in vials, and identifications and countings were made under high magnification. Identifications of the genera were made mostly following Goodey (26) and Chitwood and Chitwood (5).

Data were taken on the variety of pineapple, moisture content, soil type, previous crop, variety and age of the plants, and the appearance of the crop. Maps were drawn of each field surveyed for future reference. The $\mathrm{pH}$ determinations were made by the Central Analytical Laboratory of the Agricultural Experiment Station. Climatological data were obtained from the Weather Bureau.

A similar method was employed for collecting the roots in the field from the same places that soil samples were obtained. Fifty grams of the compound samples of roots were processed with the Waring blendor as described by Taylor and Loegering in 1953 (12). Countings and calculations were based on nematodes present in $50 \mathrm{gm}$. of roots. The roots from several plants were taken from a field to be sampled; they were weighed and the number of grams of roots per square meter and per acre were then calculated. The total number of nematodes in the roots was calculated by multiplying the number of nematodes as found in the analyzed sample by the amount of roots figured per square meter or acre. The figures obtained from the soil were then combined with those from roots of the same field to establish the total number of nematodes in a square meter and an acre of the field. In this way not only the number of nematodes free in the soil was figured, but also those which are found in the roots (endoparasites) and which usually escape observation when soil samples only are studied. Direct observation of the roots was necessary to detect the presence of adult female root-knot and reniform nematodes, but no estimations of these nematodes were made because of difficulties in observations.

Recognized plant-parasitic nematodes were recorded, and all those possessing a stylet were identified to the genus and included as possible plant parasites. Free-living and predatory forms were also identified; populations were then calculated, and the distribution of the forms was noted, but is not included here.

Calculations were made of the genera per square meter and per acre to a depth of $15 \mathrm{~cm}$. Climatological data, as well as biological factors, were taken into consideration in evaluating populations. Since the Baermannfunnel method is supposed to be only from 50- to 75-percent correct, corrections to secure the final numbers were made multiplying these by 1.5 . 


\section{RESULTS AND OBSERVATIONS}

From the 60 compound samples studied 23 different genera were identified, 16 of which are known to be serious plant parasites and 7 are suspected to be such. All those forms which possess a stylet were included as suspected parasites, although some of them might not be plant feeders at all.

\section{GENERAL DISTIRLBUTION}

Occurrence and percentages of the 23 genera are given in tables 1 and 2. There we can see that Rotylenchulus reniformis, the reniform nematode, and Helicotylenchus spp., spiral nematodes, were the most numerous, being found in all samples. Pratylenchus spp., the meadow nematodes, Ditylenchus spp., bulb and stem nematodes, and Paratylenchus spp., pin nematodes, were also numerous with $93.3,88.3$, and 73.3 percent of the samples, respectively. Meloidogyne spp., the root-knot nematode, were generally distributed along the North Coast, where sandy and loamy-humid soils prevail, but were not found in the other two Regions. Of the suspected plant parasites the most numerous were Aphelenchoides spp. and Dorylaimus spp., with a percentage occurrence of 70.00 and 66.66 , respectively.

As a rule not less than 5 different parasitic genera were present in 1 sample and no more than 15 , with a mean average of 9 per sample. In the Northern Region all of the 23 genera were present. In the Southwestern Region only 9 genera were found against 12 in the Central Region.

The distribution of the genera in the three different regions and their respective locations in each region is given in table 3 . There we find that six genera: Rotylenchulus, Helicotylenchus, Ditylenchus, Tylenchus, Seinura, and A phelenchoides are found in all locations surveyed. Other genera like Meloidogyne, Trichodorus, Diptherophora, Xiphinema, Discolaimus, Rotylenchus, Carcharolaimus, Leptonchus, Longidorus, Hemicycliophora, and Pseudohalenchus were present only on the North Coast. The Central and Southwestern Regions did not have any endemic genera. Three genera, Dorylaimus, Mytylenchus, and Criconemoides which are shared by the Northern and the Central Regions, are not found in the Southern Region where hard-dry saline soils prevail.

Only larvae, males, and preparasitic females of the reniform nematodes were observed in the samples. Although most of them were found in the soil (in 58 samples), some were also found in the 28 root samples (table 2). The spiral nematode was more or less equally abundant in soil and roots, and was present in 56 and 53 samples, respectively. Several species of this genus were present, being most common: Helicotylenchus nannus, $H$. erythrinae, and $H$. multicinctus. Pratylenchus, the meadow or lesion nematode, were more common in root samples than in the soils, being present 
in 54 and 42 samples, respectively. Pratylenchus brachyurus and $P$. zeae scemed to be the most important species of this genus. Ditylenchus spp. were also more common in root than in soil samples. Dorylaimus spp., mostly found in the soil, were present in 37 samples while only 6 of the root samples contained them. Aphelenchus, Trichodorus, Criconemoides, Diph-

TABLE 1.-The general incidence of the 28 nematode genera found in pineapple plantations in Puerto Rico

\begin{tabular}{|c|c|c|c|}
\hline Nematode genera & Common name ${ }^{1}$ & $\begin{array}{c}\text { Occur- } \\
\text { rences } \\
\text { in } 60 \\
\text { samples }\end{array}$ & $\begin{array}{c}\text { Propor- } \\
\text { tional } \\
\text { occur- } \\
\text { rences }\end{array}$ \\
\hline & & Number & Percenl \\
\hline \multicolumn{4}{|l|}{ Tylenchidae Filipjev, 1934} \\
\hline Ditylenchus Filipjev, 1934 & Bulb and stem nematode & 53 & 88.33 \\
\hline Tylenchus Bastian, 1865 & & 33 & 55.00 \\
\hline Mytylenchus² & & 30 & 50.00 \\
\hline Pseudohalenchus Tarjan, 1958 & False Halenchus nematode & 3 & 5.00 \\
\hline $\begin{array}{l}\text { Hoplolaimidae Filipjev, 1941, Wie- } \\
\text { ser, } 1953\end{array}$ & & & \\
\hline Helicotylenchus Steiner, 1945 & True spiral nematode & 60 & 100.00 \\
\hline Rotylenchus Filipjev, 1934 & Spiral nematode & 3 & 5.00 \\
\hline Pratylenchus Filipjev, 1934 & Meadow nematode & 56 & 93.33 \\
\hline \multicolumn{4}{|l|}{ Family undetermined } \\
\hline $\begin{array}{c}\text { Rotylenchulus Linford \& Oli- } \\
\text { veira, } 1940\end{array}$ & Reniform nematode & 60 & 100.00 \\
\hline Heteroderidae Thorne, 1949 & & & \\
\hline Meloidogyne Goeldi, 1889 & Root-knot nematode & 39 & 65.00 \\
\hline \multicolumn{4}{|l|}{ Criconematidae Thorne, 1943} \\
\hline Criconemoides Taylor, 1936 & Ring nematode & 10 & 18.33 \\
\hline Paratylenchus Micoletzky, 1922 & Pin nematode & 44 & 73.33 \\
\hline Hemicycliophora de Man, 1921 & Sheath nematode & 1 & 1.66 \\
\hline \multicolumn{4}{|l|}{ Aphelenchidae Steiner, 1949} \\
\hline Aphelenchoides Fisher, 1894 & Foliar nematode & 42 & 70.00 \\
\hline Aphelenchus Bastian, 1865 & & 21 & 35.00 \\
\hline Seinura Fuchs, 1934 & & 24 & 40.00 \\
\hline \multicolumn{4}{|l|}{ Dorylaimoidea Thorne, 1934} \\
\hline Xiphinema Cobb, 1913 & Dagger nematode & 3 & 5.00 \\
\hline Longidorus Micoletzky, 1922 & & 1 & 1.66 \\
\hline Trichodorus Cobb, 1913 & Stubby root nematode & 10 & 18.33 \\
\hline Dorylaimus Dujardin, 1845 & Spear nematode & 40 & 66.66 \\
\hline Discolaimus Cobb, 1913 & & 3 & 5.00 \\
\hline Diphlherophura de Man, 1880 & & 4 & 6.66 \\
\hline Carcharolaimus Thorne, 1939 & & 1 & 1.66 \\
\hline Leptonchus Cobb, 1920 & & 1 & 1.66 \\
\hline
\end{tabular}

1 Some from Buhrer (1954).

2 Undescribed genus related to Ditylenchus and Tylenchus. 
therophora, Xiphinema, Discolaimus, Leptonchus, Longidorus, and Hemicycliophora were most common in soil samples; the last 7 were not seen in root samples. Other genera like Meloidogyne, Paratylenchus, and Tylenchus were more or less equally present in both root and soil samples. Mytylenchus, Seinura, Aphelenchoides, Rotylenchus, and Pseudohalenchus were

TABLE 2.-Incidence of the observed nematode genera in 60 samples of soil and roots in Puerto Rico

\begin{tabular}{l|c|c|c|c}
\hline \multicolumn{1}{c|}{ Nematode genus } & \multicolumn{3}{|c|}{ Soil } & \multicolumn{2}{c}{ Roots } \\
\cline { 2 - 5 } \cline { 2 - 5 } Rotylenchulus & Number & Percent & Number & Percent \\
Helicotylenchus & 59 & 98.33 & 28 & 46.67 \\
Pratylenchus & 58 & 96.67 & 53 & 88.33 \\
Ditylenchus & 43 & 71.67 & 54 & 90.00 \\
Dorylaimus & 35 & 58.33 & 48 & 80.00 \\
Meloidogyne & 37 & 61.67 & 6 & 10.00 \\
Paratylenchus & 29 & 48.33 & 24 & 40.00 \\
Tylenchus & 28 & 46.67 & 36 & 60.00 \\
Aphelenchus & 21 & 35.00 & 23 & 38.33 \\
Mytylenchus & 16 & 26.67 & 6 & 10.00 \\
Criconemoides & 10 & 16.67 & 27 & 45.00 \\
Trichodorus & 9 & 15.00 & - & - \\
Seinura & 9 & 15.00 & 1 & 1.67 \\
Diphtherophora & 8 & 13.33 & 21 & 35.00 \\
Xiphinema & 4 & 6.67 & - & - \\
Aphelenchoides & 3 & 5.00 & - & - \\
Discolaimus & 4 & 6.67 & 40 & 66.67 \\
Rotylenchus & 2 & 3.33 & - & - \\
Carcharolaimus & 1 & 1.67 & 2 & 3.33 \\
Leplonchus & 1 & 1.67 & - & - \\
Longidorus & 1 & 1.67 & - & - \\
Hemicycliophora & 1 & 1.67 & - & - \\
Pseudohalenchus & 1 & 1.67 & - & - \\
& - & - & 2 & 3.33 \\
\hline
\end{tabular}

1 Undescribed.

decidedly more common in root than in soil samples; the last one was observed in root samples only.

\section{SIZE AND COMPOSITION OF POPULATIONS}

As might be expected, the two genera (Rotylenchulus and Helicotylenchus) which were generally distributed in all the samples examined were also the most abundant. Rolylenchulus outnumbered all the other genera except in the locations of Manatí, Lajas, and Corozal, where Helicotylenchus was more numerous. Beside these two only four other species, e.g. Pratylenchus, 
Dorylaimus, Paratylenchus, and Tylenchus appeared to be remarkably numerous in all the regions; Meloidogyne spp. was found in all localities of the North Region.

The total average number of nematodes per square meter in the whole production area for the Island was 1.75 millions ( 7.05 billion per acre) which

TABLE 3.-Distribution of the 29 genera of nematodes in 60 samples of soil and roots from 8 different locations in 8 Regions of Puerto Rico

\begin{tabular}{|c|c|c|c|c|c|c|c|c|}
\hline \multirow{2}{*}{ Nematode genus } & \multicolumn{5}{|c|}{ Northern Region } & \multirow{2}{*}{$\begin{array}{c}\text { Southwestern } \\
\text { Region, } \\
\text { Lajas }\end{array}$} & \multicolumn{2}{|c|}{ Central Region } \\
\hline & $\begin{array}{l}\text { Barce- } \\
\text { loneta }\end{array}$ & Manats & $\begin{array}{l}\text { Vega } \\
\text { Baja }\end{array}$ & $\begin{array}{l}\text { Vega } \\
\text { Alta }\end{array}$ & Arecibo & & $\begin{array}{c}\text { Las } \\
\text { Piedras }\end{array}$ & Corozal \\
\hline Rotylenchulus & 21 & 10 & 8 & 4 & 6 & 3 & 6 & 2 \\
\hline Helicotylenchus & 21 & 10 & 8 & 4 & 6 & 3 & 6 & 2 \\
\hline Pratylenchus & 21 & 7 & 8 & 4 & 6 & 3 & 5 & - \\
\hline Ditylenchus & 16 & 8 & 8 & 4 & 6 & 3 & 5 & 2 \\
\hline Dorylaimus & 17 & 5 & 5 & 3 & 4 & - & 5 & 1 \\
\hline Meloidogyne & 19 & 4 & 8 & 3 & 4 & - & - & - \\
\hline Paralylenchus & 12 & 8 & 8 & 2 & 5 & 3 & 6 & 一 \\
\hline Tylenchus & 9 & 5 & 5 & 3 & $\mathbf{5}$ & 1 & 4 & 1 \\
\hline Aphelenchus & 9 & 2 & 2 & - & 2 & 3 & 2 & 1 \\
\hline Mytylenchus ${ }^{1}$ & 15 & 6 & 一 & 2 & - & - & 5 & 2 \\
\hline Criconemoides & 4 & 一 & 3 & 1 & 一 & - & 2 & - \\
\hline Trichodorus & 9 & - & 1 & 一 & - & - & - & - \\
\hline Seinura & 2 & 4 & 6 & 1 & 5 & 1 & 4 & 1 \\
\hline Diphtherophora & 3 & - & 1 & - & - & - & - & - \\
\hline Xiphinema & 3 & - & - & - & - & - & - & - \\
\hline Aphelenchoides & 12 & 7 & 6 & 3 & 5 & 2 & $\mathbf{5}$ & 2 \\
\hline Discolaimus & 3 & - & - & - & 一 & - & - & 一 \\
\hline Rotylenchus & 4 & - & 1 & - & 1 & - & - & - \\
\hline Carcharolaimus & 1 & - & - & - & - & - & - & - \\
\hline Leplonchus & 1 & 一 & - & - & - & 一 & - & - \\
\hline Longidorus & 1 & - & - & - & - & 一 & - & - \\
\hline Hemicycliophora & - & - & - & 1 & - & - & - & 一 \\
\hline Pseudohalenchus & - & 2 & - & - & - & 一 & - & - \\
\hline
\end{tabular}

1 Undescribed.

is considered high. The lowest number was 0.29 millions per square meter (1.17 billion per acre), which was found in 1 sample from the Southwestern Region. The highest number calculated to be present in a sample was 5.87 million per square meter, or 23.72 billion per acre, found in 1 of the 21 samples collected in the location of Barceloneta, in the Northern Region.

Northern Region

The Northern Region, which extends from Bayamón to Isabela, is the most important pineapple production area. Here two pineapple varieties, 
Red Spanish and Smooth Cayenne, are cultivated. The soil is mostly sandy and sandy loam, although heavier soils are present. There is a high precipitation which insures enough humidity for the growth of pineapple plants. Temperatures are mild and constant moisture-laden winds blow from the Atlantic Ocean. Here certain fields have been used for pineapple production for more than 20 consecutive years, but crop rotation is generally applied. Most of the areas are at sea level with small elevations in some places. For the purpose of the study only 5 of the most important locations in pineapple production were studied, e.g. Vega Alta, Vega Baja, Manatí, Barceloneta, and Arecibo.

In this Region the greatest number of samples, 49 , was taken; their distribution is shown in table 3 . Samples were taken during the first months of the study when the Island was facing a general drought and precipitation was very low. Only the largest fields were selected in this study since the areas in some of the sections, like Barceloneta, were too large to permit a study of every acre.

This Region had the greatest number of genera present. In fact, all of the 23 genera found over the Island were represented. Populations composed of large numbers of Rotylenchulus, Helicotylenchus, and Pratylenchus together with Paratylenchus, Ditylenchus, Meloidogyne, and Dorylaimus were very common. Usually large numbers of lesion nematodes were found in the swellings caused by the root-knot nematodes; in older swellings great numbers of the pin nematodes and free-living forms were obtained. Of the 5 locations studied in this Region the one that harbored the greatest number of genera was Barceloneta, with 22. Arecibo presented the least number with only 11 genera; Manatí had 12 and Vega Baja and Vega Alta, 13 each. As shown in table 4, Arecibo had the greatest number of parasitic nematodes in general with 3.17 millions per square meter $(12.80$ billion per acre). This was followed by Vega Baja with 2.41 million per square meter ( 8.31 billion per acre). This was a surprise because in both places soil fumigation is practiced for controlling nematodes; the plants were in good shape and promising good yield. While Barceloneta and Manatí had about equal numbers it was here that the greatest damage was noticed in the fields studied. Vega Alta had the least number of parasitic forms; here in 2 of the fields the soil was quite hard and in the other 2 the plants were very young yet.

\section{Southwestern Region}

The Southwestern Region is the smallest of the pineapple production areas of the Island. There are just a few private farms situated on mountainsides. No more than 25 acres are in production and only one variety of the plant is cultivated; this is the Bull Head (Cabezona) variety, which pro- 
duces the largest fruit. Hard clay soils prevail and the precipitation is very low. Because the elevation is high and the soils are highly saline, cultivation of the other 2 varieties of ananas is impractical. In previous years the above-mentioned variety had been planted generally, but now most of the soils are planted to sugarcane. Those areas where pineapples are produced have been planted to this crop for many years. Only 3 farms were surveyed in this Region because the other plantings were too small.

This Region showed the least number of genera. Only 9 of the 23 previously reported genera were present here, and only 6 were generally distributed. These were Rotylenchulus, Helicotylenchus, Pratylenchus, Dity-

TABLE 4.-Mean averages, lows, and highs of the nematode populations, in millions per square meter, for the different locations and Regions of pineapple plantings in Puerto Rico

\begin{tabular}{l|c|c|c}
\hline \multicolumn{1}{c|}{ Location } & Average & Lowest number & Highest number \\
\cline { 2 - 3 } Northern Region & 2.23 & 0.35 & 5.87 \\
Barceloneta & 1.90 & .35 & 5.87 \\
Manatí & 2.06 & 1.00 & 3.74 \\
Vega Baja & 2.41 & .96 & 5.74 \\
Vega Alta & 1.61 & .79 & 2.90 \\
Arecibo & 3.17 & 1.85 & 5.54 \\
Southwestern Region & .75 & .29 & 1.11 \\
Lajas & 1.09 & .49 & 1.61 \\
Central Region & 1.04 & .49 & 1.61 \\
Las Piedras & 1.15 & - & - \\
Corozal & 1.75 & 0.29 & 5.87 \\
Total & & & \\
\hline
\end{tabular}

lenchus, Paratylenchus, and Aphelenchus. Aphelenchoides was found in 2 of the samples, while Seinura and Tylenchus were found in only 1 . In this Region with clay soils the spiral nematode was the most abundant with a mean average of 0.36 millions per square meter (1.49 billion per acre), while the reniform nematode was second with an average of 0.32 millions per square meter (1.26 billions per acre). The populations of the other genera were less numerous. The average number of plant parasitic nematode per square meter was 0.75 million ( 3 billion per acre).

\section{Central Region}

The third Region studied and the second one in importance is the Central Region. This area consists of certain sections in the mountains. Because some of the pineapple plantations are disappearing, only two of the sec- 
tions were included in the study. The most important of the two was Las Piedras, where Red Spanish is mostly cultivated. In the Corozal area pineapple production is disappearing, but a few acres are still devoted to experimentation by the Agricultural Substation. These were surveyed. The temperature in this mountain Region is lower than it is in the other areas; precipitation is reasonably high and humidity is constant. Elevation is high, but in Las Piedras the land offers facilities for mechanization. Here soil fumigation for the control of nematodes is also used. Six samples were taken from different fields, in which the plantings ranged from 6 months to 3 years in age. Some of the fields were new; others have been cultivated with ananas for many years.

In Corozal the land is of a higher elevation and steep; here many former pineapple fields are no longer planted to this crop. Humidity is high and temperature is lower than in the Coastal Region. Only two samples were taken, one each from Red Spanish and Smooth Cayenne.

Twelve nematode species were present; this is 3 more than in the Southwestern Region and 11 less than in the Northern Region. The reniform nematode (Rotylenchulus), the spiral nematode (Helicotylenchus), and $M y$ tylenchus were universally distributed among all samples, followed by $D i$ tylenchus and Aphelenchoides which were present in seven of the samples. The spiral nematode was the most abundant in this Region with a mean average of 0.56 million per square meter ( 2.23 billions per acre); the reniform nematode was second with 0.35 million per square meter ( 1.39 billions per acre). In Las Piedras Rolylenchulus was more abundant with 0.35 million per square meter ( 2.60 billions per acre) as compared with Helicotylenchus having 0.19 million per square meter ( 0.75 billion per acre). In Corozal only 0.05 million per square meter ( 0.19 billion per acre) of Rotylenchulus nematodes were present and 0.92 million spirals per square meter (3.71 billions per acre). The populations of the other parasitic forms were much lower. As shown in table 4 the number of plant parasitic nematodes per square meter averaged 1.09 millions for the whole Central Region; Las Piedras showed 1.04 millions and Corozal, 1.15 millions. The average number for all the other genera are shown in table 5.

\section{FACTORS INFLUENCING THE POPULATIONS}

One of the most important phases of nematology is the study of the ecological factors affecting the presence of nematode populations. Bionomic studies have been conducted in Hawaii $(14,19,20,22,24,25,27,29,33)$ in relation to the effects of the root-knot nematode on pineapple roots. In other places, such as Florida, in addition to research on the citrus disease, extensive ecological studies have been made. Besides these and some other 
TABLE 5.-Nematode genera per location and the mean population number in relation to the pineapple production areas of Puerto Rico

\begin{tabular}{|c|c|c|c|c|c|c|c|c|c|}
\hline \multirow{3}{*}{ Nematode genus } & \multicolumn{9}{|c|}{ Average number of nematodes per location and region in millions per square meter } \\
\hline & \multicolumn{5}{|c|}{ Northern Region } & \multirow{2}{*}{$\begin{array}{c}\text { South- } \\
\text { western } \\
\text { Region, } \\
\text { Lajas }\end{array}$} & \multicolumn{2}{|c|}{ Central Region } & \multirow{2}{*}{ Average } \\
\hline & Barceloneta & Manatí & Vega Baja & Vega Alta & Arecibo & & Las Piedras & Corozal & \\
\hline Rotylenchulus & $1,118,606$ & 845,070 & $1,383,741$ & $1,208,830$ & $2,080,553$ & 311,341 & 642,451 & 46,949 & 954,692 \\
\hline Helicotylenchus & 375,586 & 852,483 & $1,008,154$ & 316,283 & $1,420,805$ & 368,173 & 185,323 & 916,728 & 680,442 \\
\hline Pratylenchus & 44,478 & 59,303 & 88,955 & 37,064 & 160,613 & 9,884 & 7,413 & - & 50,964 \\
\hline Ditylenchus & 19,768 & 27,181 & 27,181 & 12,355 & 29,652 & 14,826 & 42,006 & 1,235 & 21,775 \\
\hline Dorylaimus & 709,107 & 395,354 & 56,832 & 42,006 & 29,652 & - & 126,019 & 74 & 169,888 \\
\hline Meloidogyne & 49,419 & 34,594 & 101,310 & 1,236 & 86,484 & - & - & - & 34,130 \\
\hline Paratylenchus & 7,413 & 59,303 & 71,658 & 1,236 & 59,303 & 7,413 & 74,129 & - & 35,057 \\
\hline Tylenchus & 19,768 & 12,355 & 14,826 & 42,006 & 19,768 & 29,652 & 37,064 & 44,477 & 27,490 \\
\hline Aphelenchus & 19,768 & 7,413 & - & - & 7,413 & 22,239 & 7,413 & - & 9,884 \\
\hline Mytylenchus ${ }^{1}$ & 7,413 & 741 & 29,303 & 74,129 & - & - & 130,961 & 118,606 & 41,481 \\
\hline Criconemoides & 74,729 & - & - & 44,477 & - & - & 143,316 & - & 36,403 \\
\hline Trichodorus & 29,652 & - & 2,718 & - & - & - & - & - & 3,707 \\
\hline Seinura & 148 & 12,355 & 14,826 & 124 & 7,413 & 222 & 22,238 & - & 5,652 \\
\hline Diphtherophora & 14,826 & - & - & - & - & - & - & - & 3,706 \\
\hline Xiphinema & 22,239 & - & 741 & - & - & - & 一 & - & 2,780 \\
\hline Aphelenchoides & 222 & 247 & - & 741 & 11,483 & 741 & 7,413 & 148 & 1,469 \\
\hline Discolaimus & 22,239 & - & - & - & - & - & - & - & 2,780 \\
\hline Rotylenchus & 7,413 & - & - & - & - & - & - & - & 927 \\
\hline Carcharolaimus & 1,235 & - & 一 & 一 & - & - & - & - & 154 \\
\hline Leplonchus & 1,235 & - & - & - & - & - & - & - & 154 \\
\hline Longidorus & 14,826 & - & - & - & - & - & - & - & 1,853 \\
\hline Hemicycliophora & - & - & - & 29,652 & - & - & - & 一 & 3,707 \\
\hline Pseudohalenchus & 247 & - & - & - & - & - & - & - & 031 \\
\hline
\end{tabular}

1 Undescribed. 
scattered studies not much has been done, and investigators mostly speculate.

A common question raised in connection with soil and plant nematodes concerns the depth of their penetration into the soil and the location of their maximal concentration-in other words, the relationship of the soil profile to the occurrence of plant nematodes. The A horizon, of course, is that of the main concentration because most of the roots grow there; but the B horizon may be penetrated also wherever roots grow in it and organic material is present. Available food, temperature, moisture, and soil structure are the factors determining the distribution maxima, which accordingly may be near the surface or deeper in the soil.

By its structural composition the soil offers plant nematodes favorable conditions for a cavernicolous life; conditions such as: 1 , Pore space with moisture-saturated air; 2, a film of moisture over the particles of soil; 3 , a narrow temperature amplitude slow in its changes; and 4, good protection from light and the lethal action of the rays of the sun (43). Thus, a porous soil is particularly suitable for the nematode; sandy soils have long been known to favor plant nematodes and especially to promote their spread. Heavy clay soils are not exclusive and preventive of plant-nematode infestation, but they have a restraining effect on nematode spread.

\section{Humidity}

Moisture is a crucial soil factor for conditioning the activities of plant nematodes. Proper moisture promotes nematode survival; it particularly makes locomotion and migration possible. Drought, on the other hand, is inimical to nematodes. As a protection from drought some plant nematodes can enter a state of dormancy and revive when sufficient moisture is available. This adaptation may reach a climax in special phenomena such as that observed in some species of Ditylenchus, where hundreds of thousands of specimens may aggregate during dormancy and form curl-like masses. On the other hand, excess of moisture in the form of water is detrimental to certain plant nematodes. For example, the flooding of land for prolonged periods of 3 months or more may reduce root-knot infestations.

Table 6 shows the relationship of moisture based on the average rainfall (precipitation) to nematode population numbers in five of the locations. Since climatological data were not available for three locations, a general statement as to the relationship of these factors on nematode populations cannot be made. No apparent relationship was noted in the distribution of nematode populations according to average rainfall except for root-knot the population of which decreased as rainfall increased in the North Coast. In Arecibo where precipitation was lower than in the other two locations of the Northern Region, the population numbers wcre higher for all the 
genera as well as for the three genera mentioned in table 6. In Corozal, where precipitation is high, nematodes were more numerous in general than in Lajas; the reniform nematode was much less frequent while spiral nematodes were more numerous.

\section{Temperature}

In addition to humidity or moisture, temperature is one of the most important factors affecting the distribution of plant nematode populations. Some species of nematodes can endure high temperatures, like those living in hot springs and others inhabiting desert soils. Other species on the contrary, are susceptible to high temperatures and are paralyzed or killed

TABLE 6.-Temperature and rainfall in relation to nematode population for 5 of the locations in Puerto Ricol

\begin{tabular}{|c|c|c|c|c|c|c|}
\hline \multirow{2}{*}{ Location } & \multirow{2}{*}{$\begin{array}{l}\text { Average air } \\
\text { temperature }\end{array}$} & \multirow{2}{*}{$\begin{array}{l}\text { Rainfall } \\
\text { precipitation per } \\
\text { year }\end{array}$} & \multicolumn{4}{|c|}{ Nematodes per square meter } \\
\hline & & & All genera & $\begin{array}{l}\text { Rolylent- } \\
\text { clisulus }\end{array}$ & $\underset{\text { tylenchus }}{\text { Belico- }}$ & $\begin{array}{l}\text { Mfeloi- } \\
\text { dogyne }\end{array}$ \\
\hline & ${ }^{\circ} \boldsymbol{F}$ & Inches & Millons & Mrillions & Mrillions & Mrillions \\
\hline Arecibo & 76.6 & 56.83 & 3.17 & 2.00 & 1.42 & 0.09 \\
\hline Barceloneta & - & 58.90 & 1.90 & 1.19 & .38 & .05 \\
\hline Manatf & 77.67 & 61.26 & 2.06 & .85 & .86 & .04 \\
\hline Lajas & 76.00 & 52.81 & .75 & .32 & .37 & - \\
\hline Corozal & 75.40 & 82.27 & 1.15 & .05 & .92 & - \\
\hline
\end{tabular}

1 Air temperature as determined by Weather Bureau and precipitation in relation to rainfall (precipitative).

when exposed. Experiments performed by Godfrey in Hawaii with the root-knot nematode have shown that the minimum lethal temperature for long exposures is $41^{\circ} \mathrm{C}$. $\left(106^{\circ} \mathrm{F}\right.$.). This temperature may occur in fields to a depth of at least 2 and sometimes 3 inches, thereby eliminating live nematodes from the upper soil layers. Temperature plays an important part in nematode infection and in the length of their life cycles. Godfrey has stated that $13^{\circ} \mathrm{C}$. $\left(55.5^{\circ} \mathrm{F}\right.$.) is the approximate minimum temperature at which any extensive infection will take place.

The soil offers plant nematodes a shelter against rapid and extreme temperature changes. Plant nematodes with a permanent soil phase, that is those living on biennial or perennial hosts, may be more or less active even through off-season periods, unless frost and extreme heat induce them to dormancy.

Temperature may have its effect in two ways: in its limitations on the actual life of the organism causing the disease, and in its effect on the num- 
ber of generations that may be produced even if the organism can remain alive throughout the year.

In temperate countries like the United States seasonal population variations occur and are mostly influenced by temperature changes and its effect upon the plant nematodes. In Puerto Rico this is not the case since the temperature is almost constant throughout the year. The mean average temperature for winter is $73^{\circ} \mathrm{F}$. $\left(23^{\circ} \mathrm{C}\right.$.) and that for the summer is $79^{\circ} \mathrm{F}$. $\left(26^{\circ} \mathrm{C}\right.$.) with a difference of only $6^{\circ} \mathrm{F}$, although there might be marked differences in some places. For this reason, it is assumed that plant nematode populations do not vary much during winter and summer. No study of this nature has been undertaken.

As shown in table 6 temperature data were available for only four locations. The mean temperature for these places is given in addition to the average populations for all the genera combined and for three of the most common genera. In the two locations of the Northern Region the results showed a general decrease of nematode population numbers where the temperature was higher. In Lajas, although temperature appeared to be lower than in the first two areas, greater extremes of temperature occurred. The maximum average temperature was $91^{\circ} \mathrm{F} .\left(33^{\circ} \mathrm{C}\right.$.) and the minimum average was $58^{\circ} \mathrm{F}$. $\left(14.5^{\circ} \mathrm{C}\right.$.). Again an increase of nematodes was noted in Corozal, which has lower temperatures. In general, more nematodes were found in Corozal than in Lajas, and the same was true with Helicotylenchus, the spiral nematode, but was negative with the reniform nematode.

\section{Soil Types}

It has been well known for years that certain plant nematodes, such as the root-knot nematode, are more numerous in sandy soils or sandy loams than in clay soils. Table 4 shows the distribution of nematode populations in the different Regions and locations. The North Coast, where the soils are mostly sandy or sandy loam, had the highest mean average of nematodes per square meter (2.23 millions). The Central Region, which as clay soils, has a lower number of nematodes than does the Northern; and the Southwestern Region, where soils are very hard clay, the average population number is still lower.

On the North Coast the soils varied from light sand to hard clay in some locations. Table 7 shows the distribution of the samples taken in the various kinds of soil in the Northern Region and the average number of nematodes, in general, as well as of three of the most common genera. The sandy loams had the greatest number of nematodes with 2.98 millions per square meter (12.05 billions per acre). This soil offers the most suitable environment for them since it is of loose structure and is rich in organic matter. Sandy soils had lower nematode populations. The nematode genera were numerous in 
clay loams but not in hard clay soils. In general, the sandy soils harbored the greatest number of parasitic nematodes with 2.45 millions per square meter (9.90 billions per acre) as compared with 1.97 millions per square meter (7.76 billions per acre) for clay soils. This represents a difference of 0.58 millions per square meter (2.34 billions per acre).

The reniform nematode followed almost the same numerical pattern as did the average of all genera. Its populations were highest in sandy loams but were also high in clay soils. Again, the reniform nematode was more numerous in the sandy soils (in general) than in clay soils; these numbers being 1.35 and 1.00 millions per square meter (5.46 and 4.06 billions per acre), respectively, a difference of 0.35 million per square meter (1.40 bil-

TABLE 7.-Nematode population in millions per square meter of genera in relation to the type of soil for soils of the Northern Region of Puerto Rico'

\begin{tabular}{l|c|c|c|c|c}
\hline \multirow{2}{*}{ Type of soil } & \multirow{2}{*}{ Samples } & \multicolumn{4}{|c}{ Population of- } \\
\cline { 2 - 6 } & & $\begin{array}{c}\text { Rolylen- } \\
\text { cliulus }\end{array}$ & $\begin{array}{c}\text { Helico- } \\
\text { tylenchus }\end{array}$ & Meloidogyne & All 23 genera \\
\cline { 3 - 6 } & Number & Millions & Mfillions & Mrillions & Mrillions \\
Sandy & 8 & 1.06 & 1.00 & 0.04 & 2.19 \\
Hard sand & 3 & .91 & .48 & .008 & 1.61 \\
Sandy loam & 14 & 2.10 & .73 & .07 & 2.98 \\
Clay loam & 9 & .94 & .58 & .10 & 1.74 \\
Clay & 8 & 1.42 & .52 & .06 & 2.17 \\
Hard clay & 7 & .67 & .92 & .06 & 1.83 \\
\hline
\end{tabular}

1 The classification of soil types is an artificial one based on field observations and not on laboratory tests.

lions per acre). The occurrence of spiral nematode populations was almost the same in all soils, but was slightly higher in sandy and hard clay soils. The average populations for sand and clay soils in general were 0.74 and 0.67 million per square meter ( 2.99 and 2.71 billions per acre) respectively. The root-knot nematode was slightly more numerous in clay than in sandy soils, with an average of 0.07 and 0.05 million per square meter $(0.27$ and 0.17 billion per acre) respectively, but was found in only a few of the samples from clay soils. Sandy and clay loams harbored the highest number of Meloidogyne spp.

Soil $p H$

Soil $\mathrm{pH}$ conditions do not appear to be selective or conditioning factors of much significance for plant nematodes. Early claims that high alkalinity of a soil reduces the incidence of root-knot nematode infections have not been confirmed by later tests (table 8). 
All the soils from which samples were taken appeared to be acid. The $\mathrm{pH}$ ranged from 3.65 to 5.82 . No marked differences in $\mathrm{pH}$ at different locations were noted. Table 8 shows the mean average $\mathrm{pH}$ (calculated by converting figures to: $\mathrm{pH}=-\log [\mathrm{H}])$ for the different localities and its relation to the mean averages of nematode population numbers in the respective places. This is shown also for the more abundant genera, Rotylenchus, Helicotylenchus, and Meloidogyne. In none of them is there any reasonable correlation with the $\mathrm{pH}$. It should be noted here that many other factors are present, which might be the cause of the lack of correlation.

TABLE 8. -The $p H$ values for different localities and their relation to average numbers of nemalodes in general and to those of the most common genera in Puerto Rico

\begin{tabular}{|c|c|c|c|c|c|}
\hline \multirow{2}{*}{ Location } & \multirow{2}{*}{$\mathrm{pH}$} & \multicolumn{4}{|c|}{$\begin{array}{l}\text { Millions of nematodes per square } \\
\text { meter }\end{array}$} \\
\hline & & $\begin{array}{l}\text { Average of all } \\
23 \text { genera }\end{array}$ & $\begin{array}{l}\text { Rotylen- } \\
\text { chulus }\end{array}$ & $\begin{array}{c}\text { Helico- } \\
\text { iylenchus }\end{array}$ & $\begin{array}{c}\text { Meloido- } \\
\text { Byne }\end{array}$ \\
\hline Northern Region & 3.84 & 2.22 & 1.37 & 0.82 & 0.06 \\
\hline Barceloneta & 4.21 & 1.89 & 1.19 & .38 & .05 \\
\hline Manatí & 3.85 & 2.05 & .85 & .86 & .04 \\
\hline Vega Baja & 3.66 & 2.41 & 1.39 & 1.01 & .10 \\
\hline Vega Alta & 3.84 & 1.61 & 1.21 & .30 & .001 \\
\hline Arecibo & 3.74 & 3.17 & 2.00 & 1.42 & .09 \\
\hline \multicolumn{6}{|l|}{ Southwestern Region } \\
\hline Lajas & 3.85 & .74 & 3.12 & .37 & - \\
\hline Central Region & 4.25 & 1.09 & .42 & .48 & - \\
\hline Las Piedras & 4.13 & 1.03 & .64 & .20 & - \\
\hline Corozal & 4.42 & 1.15 & .05 & .92 & 一 \\
\hline
\end{tabular}

Table 9 shows 11 different pHs in Barceloneta soils (North Region). Here the precipitation, temperature, and the cultivation methods were the same, but the previous crop, age of the plants, and soil type were somewhat different. No apparent correlation was found in the general plant nematode population numbers. The occurrence of three of the most common genera are shown and in none of them was a correlation with $\mathrm{pH}$ noted. Table 10 shows the same relationship in a different kind of soil and in a different location. It shows results from the six samples taken in Las Piedras (Central Region) and their respective $\mathrm{pH}$ readings. Neither the general mean average of nematode population numbers nor the two specific genera showed any apparent relation to $\mathrm{pH}$. The root-knot nematode was not present in the samples taken at that time.

\section{Plant Varieties}

The susceptibility of different varieties of pineapple plants to nematode attack has not been studied in detail. Most of the experiments carried on 
in Hawaii have been done with the Smooth Cayenne variety, but no reference to other varieties is available. In Puerto Rico investigations have been devoted mainly to the Red Spanish variety of pineapple.

TABLE 9.-The relation between soil acidity and plant nematode population per square meter in Barceloneta soils in Puerto Ricol

\begin{tabular}{c|c|c|c|c}
\hline & \multicolumn{4}{|c}{ Millions of nematodes per square meter } \\
\cline { 2 - 5 } & $\begin{array}{c}\text { Average for all } \\
\text { 23 genera }\end{array}$ & Rotylenchulus & Helicotylenchus & Meloidogyne \\
\hline 3.84 & 2.37 & 1.84 & 0.16 & 0.05 \\
3.90 & 1.46 & 1.13 & .08 & .09 \\
3.98 & 3.47 & 2.11 & 1.05 & .00 \\
4.02 & .75 & .49 & .48 & .002 \\
4.06 & .26 & .15 & .05 & .0007 \\
4.22 & .59 & .09 & .33 & .0007 \\
4.23 & 1.31 & .47 & .67 & .12 \\
4.25 & 2.79 & 2.40 & .21 & .08 \\
4.40 & 5.86 & 5.36 & .18 & .15 \\
4.79 & 1.82 & 1.40 & .35 & .007 \\
5.82 & .44 & .16 & .20 & .03 \\
\hline
\end{tabular}

1 This table represents 11 of the samples from Barceloneta where precipitation and data on temperature were the same; the soil types did not differ markedly.

TABLE 10.-The relation between soil acidity and nematode population numbers in clay soils of Las Piedras, Central Region ${ }^{1}$

\begin{tabular}{c|c|c|c}
\hline \multirow{2}{*}{$\mathrm{pH}$} & \multicolumn{3}{|c}{ Millions of nematodes per square meter } \\
\cline { 2 - 4 } & $\begin{array}{c}\text { Average for all 23 } \\
\text { genera }\end{array}$ & Rotylenchulus & Belicotylenclius \\
\hline 3.92 & 0.72 & 0.62 & 0.002 \\
3.95 & 1.62 & .94 & .34 \\
4.10 & 1.05 & .76 & .15 \\
4.15 & .49 & .30 & .12 \\
4.23 & .70 & .49 & .05 \\
4.95 & .92 & .74 & .10 \\
\hline
\end{tabular}

1 Root-knot nematode was not found to be present.

Three varieties of pineapple are being cultivated in Puerto Rico, i.e., Smooth Cayenne and Red Spanish, which are the most common, and the Puerto Rico Bull Head (Cabezona) variety, which is cultivated only in the Southwestern Region. Considering again Barceloneta in the Northern Region as an example, results showed that Smooth Cayenne Variety is more susceptible to plant nematodes in general than Red Spanish (table 11). Here 
the average number of nematode individuals of all genera was 1.35 and 2.10 millions per square meter (5.46 and 8.46 billions per acre) found for Red Spanish and Smooth Cayenne, respectively. The same was true with Rotylenchulus. Red Spanish had a population of 0.69 million per square meter, while from Smooth Cayenne 1.64 millions per square meter were obtained. The spiral and the root-knot nematodes showed opposite behavior. These two were more abundant in the Red Spanish variety, which suggests that they prefer this variety of pineapple, or that it is more susceptible to

TABLE 11.-The relationship of \& pineapple varieties, Smooth Cayenne and Red Spanish as to average number of nematodes, and to 3 genera of nematodes in Barceloneta, Northern Region of Puerto Rico

\begin{tabular}{l|c|c}
\hline \multirow{1}{*}{ Group } & \multicolumn{2}{|c}{ Population in millions per square meter for- } \\
\cline { 2 - 3 } & Red Spanish & Smooth Cayenne \\
\hline Average for 23 genera & 1.35 & 2.10 \\
Rotylenchulus & 0.69 & 1.64 \\
Helicotylenchus & .05 & .04 \\
Meloidogyne & .04 & .02 \\
\hline
\end{tabular}

TABLE 12.-Average numbers of nematodes for the 3 varieties of pineapple and the total number of samples of each examined from all locations in Puerto Rico

\begin{tabular}{l|c|c}
\hline \multicolumn{1}{c|}{ Variety } & Samples & $\begin{array}{c}\text { Mean average of nematodes per } \\
\text { square meter }\end{array}$ \\
\cline { 2 - 3 } & Number & Millions \\
Smooth Cayenne & 15 & 2.12 \\
Red Spanish & 42 & 2.00 \\
Puerto Rican Bull Head & 3 & .74 \\
\hline
\end{tabular}

their attack. The greatest number of plant nematodes in one sample (5.87 millions per square meter) was found in one of the samples of Smooth Cayenne; while the greatest number of genera in a sample (15) was obtained from the Red Spanish variety.

In general, Smooth Cayenne had a mean average obtained from 15 plantings of this variety in the whole pineapple production area of 2.12 millions per square meter (table 12). Red Spanish pineapples had a general average of 2.00 millions per square meter, which represents 0.12 million per square meter less than that for Smooth Cayenne. Forty-two fields of Red Spanish pineapples were examined in the whole Island. The Puerto Rico Bull Head variety had an average of 0.74 million per square meter, but only three 
fields were examined. This might suggest that the Bull Head variety is the most resistant, but no significant difference was found among varieties. Experimentation is needed before general conclusions are reached.

No preference of genera was noted for a particular species of pineapple. Two genera, Rotylenchus and Xiphinema werc found in Red Spanish plants only, but they were present in only three samples. Four genera, Carcharolimus, Leptonchus, Longidorus, and Diphtherophora were found in only one sample of Smooth Cayenne and in none of the Red Spanish plants, but of these only Longidorus is known as a plant parasite. As already noted only nine genera were found in the Bull Head variety of plants in the Southwestern Region.

TABLE 13.-Nematode populations in relation to previous crops planted in Puerto Rico

\begin{tabular}{l|c|c|c}
\hline \multicolumn{1}{c|}{ Previous crops } & Samples & $\begin{array}{c}\text { Proportion of all } \\
\text { samples examined }\end{array}$ & $\begin{array}{c}\text { Nematodes in } \\
\text { millions per } \\
\text { square meter }\end{array}$ \\
\hline & Number & Percent & Number \\
Sugarcane & 22 & 41.66 & 2.30 \\
Sugarcane and grapefruit & 9 & 15.00 & 1.69 \\
Pasture & 11 & 18.34 & 2.06 \\
Crotalaria & 2 & 3.33 & 1.75 \\
Pineapple (12 to 20 years) & 16 & 20.00 & 1.72 \\
\hline
\end{tabular}

\section{Previous Crop Planted}

The previous crop planted and the amount of crop litter in a certain soil may have its influence on the populations of plant nematodes of the succeeding crop because many nematodes are more attracted by certain plant genera and species than by others. In this case some of the farms now planted to pineapple were previously in sugarcane (Saccharum officinarum) or grapefruit (Citrus maxima), or were rotated with Crotalaria species, or were in pasture composed of weeds and grasses (table 13). Some of the farms had been planted continuously with pineapple for 20 or more years.

Thirty-one (51.67 percent) of the fields studied were previously planted to sugarcane; pineapples had been cultivated for at least 6 to 12 years. The average population number of plant nematodes in these were 2.30 millions a square meter ( 9.29 billions per acre). Nine of these fields were planted at some time with sugarcane and grapefruit; the average number of nematodes found in these samples was 1.69 millions per square meter (6.81 billions per acre). Eleven (18.34 percent) samples were taken from fields previously planted with Crotalaria species. The other 16 samples had been planted with pineapple from 12 to 20 years or more, and no records of previous crops were obtained. 


\section{Other Factors}

Although no records were kept and no relationship can be established, we cannot omit from this study some other biological factors which, no doubt, influence the plant nematode populations. Besides the variety of plants and previous crops planted, the age of the plants proved to be a determining factor. Furthermore, the edaphon of the soil includes a variety of organisms that are propitious, neutral, or inimical to plant nematodes. Mention should be made of fungi, some species of which will trap nematodes with sticky substances; others may form traps to catch them. In both cases the fungi grow into the nematode body and destroy it (13). Other soil organisms which might be inimical to nematodes are: Bacteria, which cause diseases; insects, such as collembola; mites, tardigrades, millipeds, earthworms, predatory nematodes, and protozoans, that feed upon them or cause diseases in them (45).

In many of our samples mites, collembola, protozoa, and predatory nematodes, like Monochus spp. and others, were observed, but no effort was made to determine their effect upon nematode populations.

There are many edaphic factors which affect the presence and population numbers of plant nematodes. Some of these are: The mineral and chemical nature of the soil; soil brackishness; soil additions such as fertilizers, compost, manure, lime, and trace elements; as well as cultural treatments such as plowing, disking, irrigation, and spraying (45). All these factors influence and modify the relationship of a soil to its plant nematode population, but none of these problems were considered in this study.

\section{DAMAGE AS RELATED TO POPULATIONS}

Observations showed that, in general, fields heavily infested with plantparasitic nematodes had less vigorous plants, suggesting nematode attack symptoms. The aerial parts of the plants showed signs of this, such as chlorosis accompanied by black spots and/or a reddish color of the leaves. These usually appear to form whole patches in the pineapple fields; they also show dieback of leaves, dwarfing of plants, and the subsequent reduction in yield because of tiny fruits, and, in rare cases, they may result in the death of the plants. Abnormal growth without the production of fruits was generally noted in plants of the Smooth Cayenne variety, as shown in figure 1. In some fields in Arecibo and in Vega Baja (Northern Region) where fumigation of soil had been employed for the control of nematodes and where populations were numerous, the plants were healthy and were producing good yields.

The above symptoms might have several causes. Therefore, the aboveground condition of the plant is not, alone, a reliable criterion on which to base the presence or absence of nematodes. Observation of the roots is 


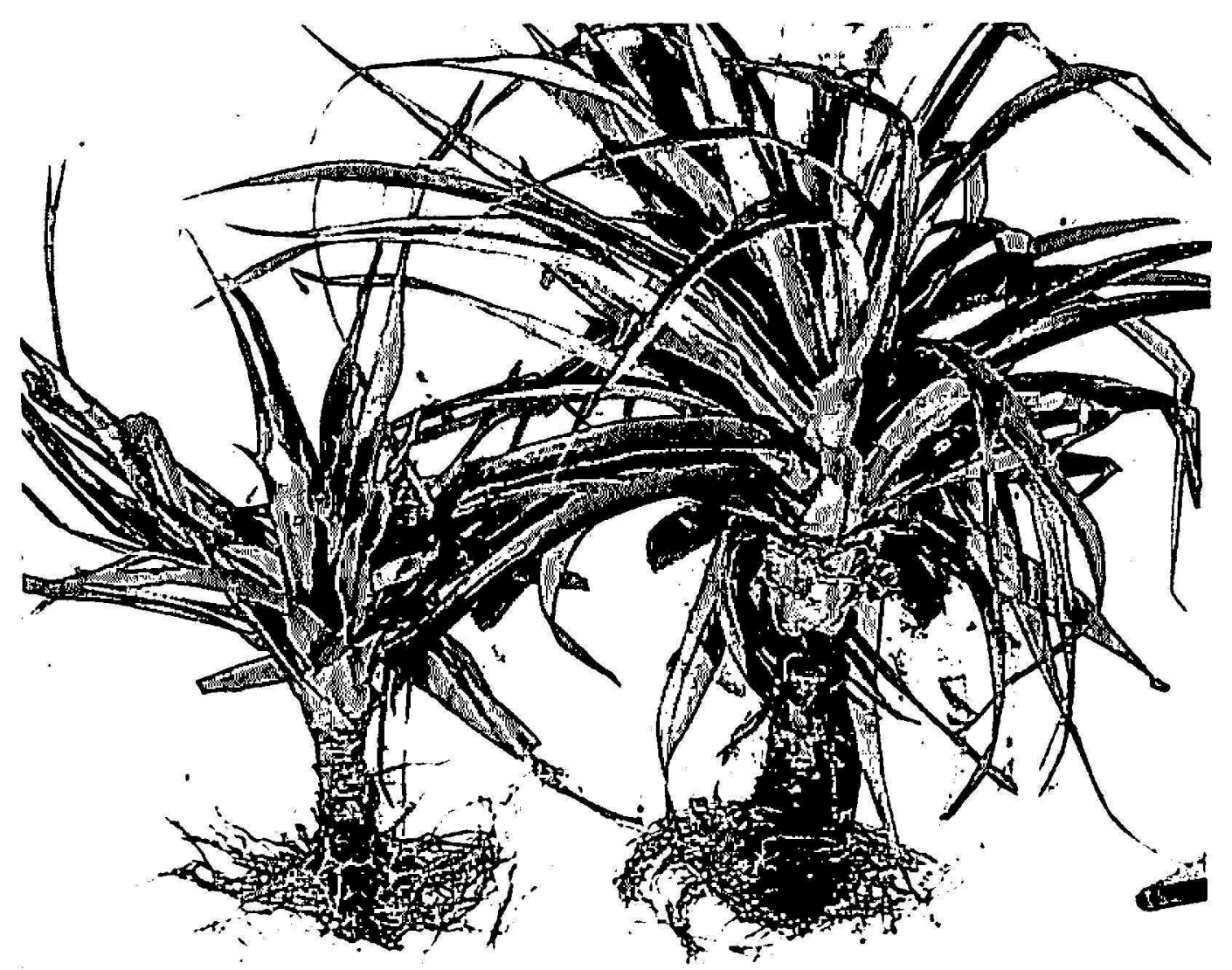

A

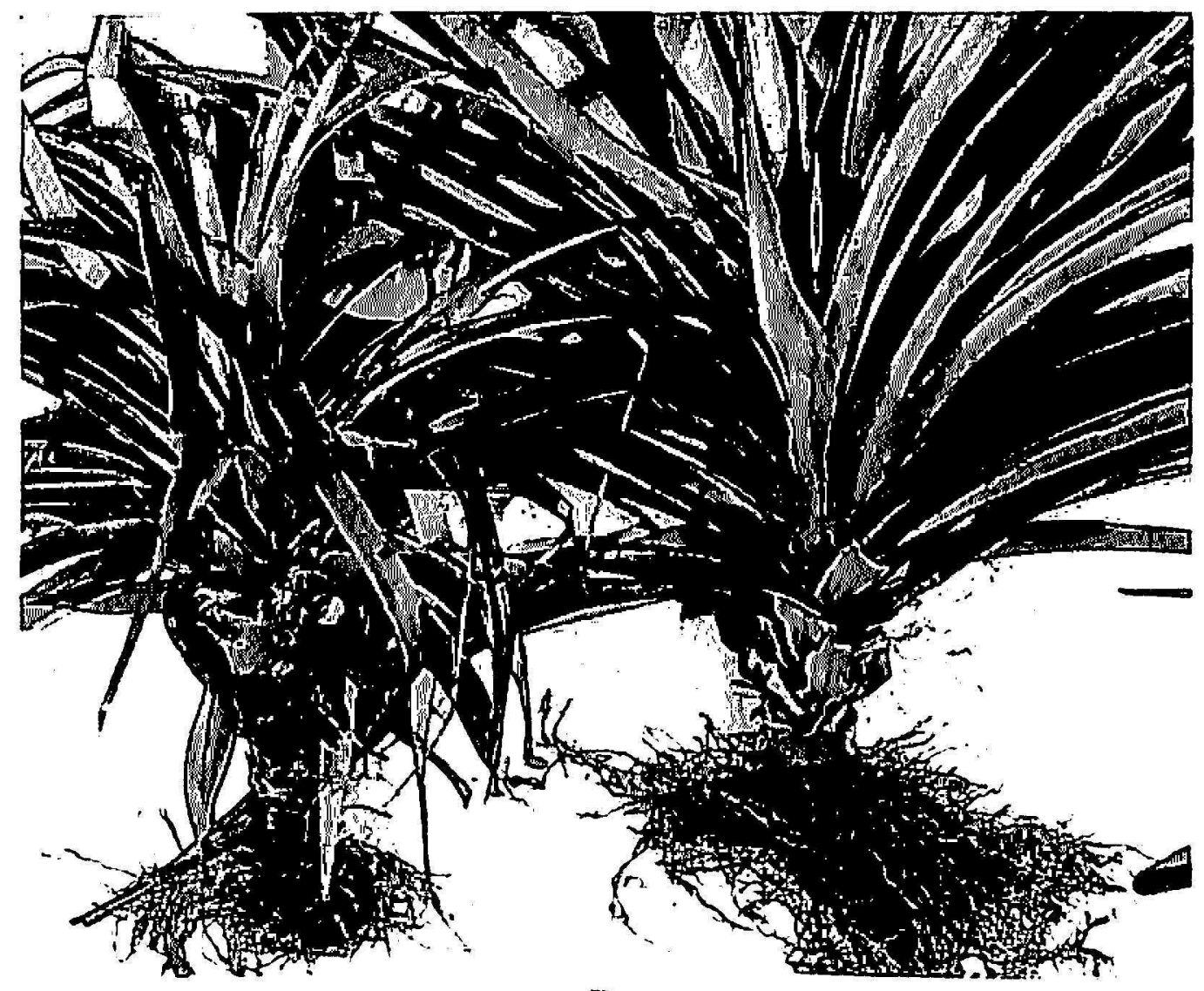

B

Fig. 1.-A, Abnormal pineapple plants of Smooth Cayeme variety which produced tiny fruit or none at all; typical chlorotic, abnormal plant producing no yield to the right, and chlorotic, stunted plant which produced tiny fruit to the left. B, Smooth Cayenne pineapple plants from the Northern Region showing an apparently healthy plant at the right and a chlorotic, stunted plant with nematode-diseased roots to the left. 
most important. The symptoms exhibited by diseased roots were numerous and varied according to the species or genera as well as the number of nematodes present in the soil. The symptoms caused by the root-knot nematode were usually easy to detect since galls were usually formed; these galls were not as large as those formed in roots of tomatoes or other plants. Main root terminal and nonterminal galls accompanied by frequent "brooming" and galls on branch rootlets constituted the visible signs of the disease in the pineapple root system. Figure 2 shows galled and "broomed" conditions of the roots. Old galls were black and cracked; usually Paratylenchus, Pratylenchus, and Aphclenchoides species were removed from the cracked galls. Free-living genera, such as Rhabditis, Cephalobus, and Eucephalobus were very common in damaged roots. Roots were frequently found exhibiting no external evidence of the root-knot disease, but on inspection under the microscope numerous females with egg masses were discovered imbedded in the tissue.

The meadow nematode has long been known to form black or brown lesions on the roots of plants. In plants wherein great numbers of these genera were found, the roots showed brown or black spots or elongated lesions. This was noted in young roots. Mature or old roots were usually completely black and very often were entirely dead. Similar symptoms might be caused by other genera, since they were noted also where reniform and spiral nematodes were numerous. Lesions, as shown in figure $2 \mathrm{~A}$, were very common in places where the last two genera prevailed. "Broomed" and stubby roots, caused by the destruction of main roots and the development of secondary and tertiary roots, were very common in all the localities. Figure 3, A, shows such roots from the Southwestern Region. Damage such as that reported to be caused by the meadow nematode could also be observed, but since the reniform and the spiral nematodes were the most numerous, these might have been the cause of at least part of the condition.

Stunted plants of Smooth Cayenne like those in figure 1, A, were very common on the North Coast, associated with great numbers of Rotylenchulus, Helicotylenchus, Meloidogyne, Pratylenchus, and Paratylenchus species. In one sample from Barceloneta, where there were 5.87 millions of nematodes per square meter (23.72 billions per acre), 5.36 millions per square meter (21.69 billions per acre) of which belonged to the reniform nematode, almost all the plants were excessively stunted and not producing any yield; they had to be destroyed after one year. Roots like those shown in figures 3 and 4 were very common. Plants such as shown in figure 3, B, possess the common type of deformed and abnormal root growth, which exists in sandy soils of Barceloneta.

Nematodes are supposed to be vertors of socalled soil-borne viruses. They are carriers and vectors of other organisms surh as bacteria and fungi. 


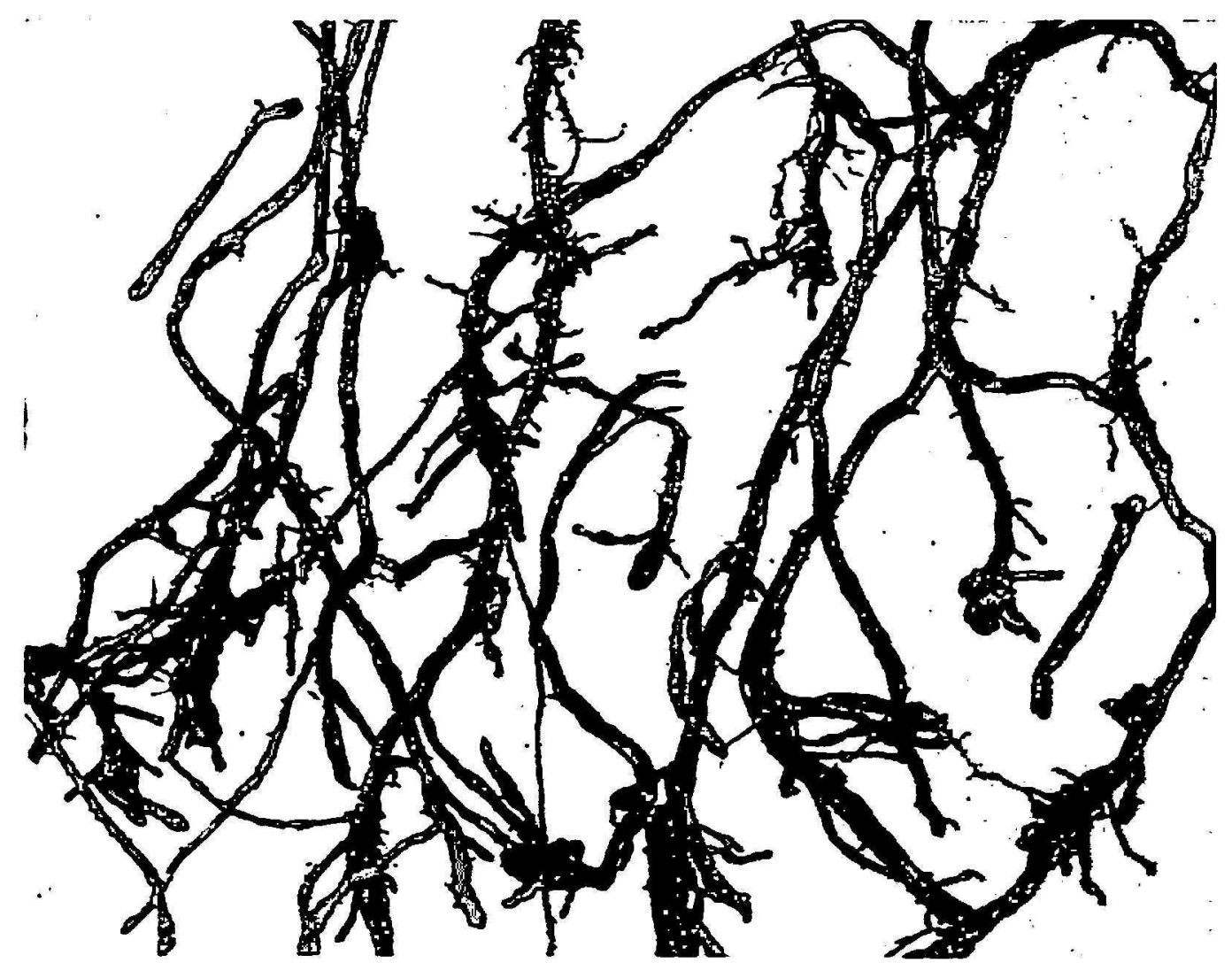

A

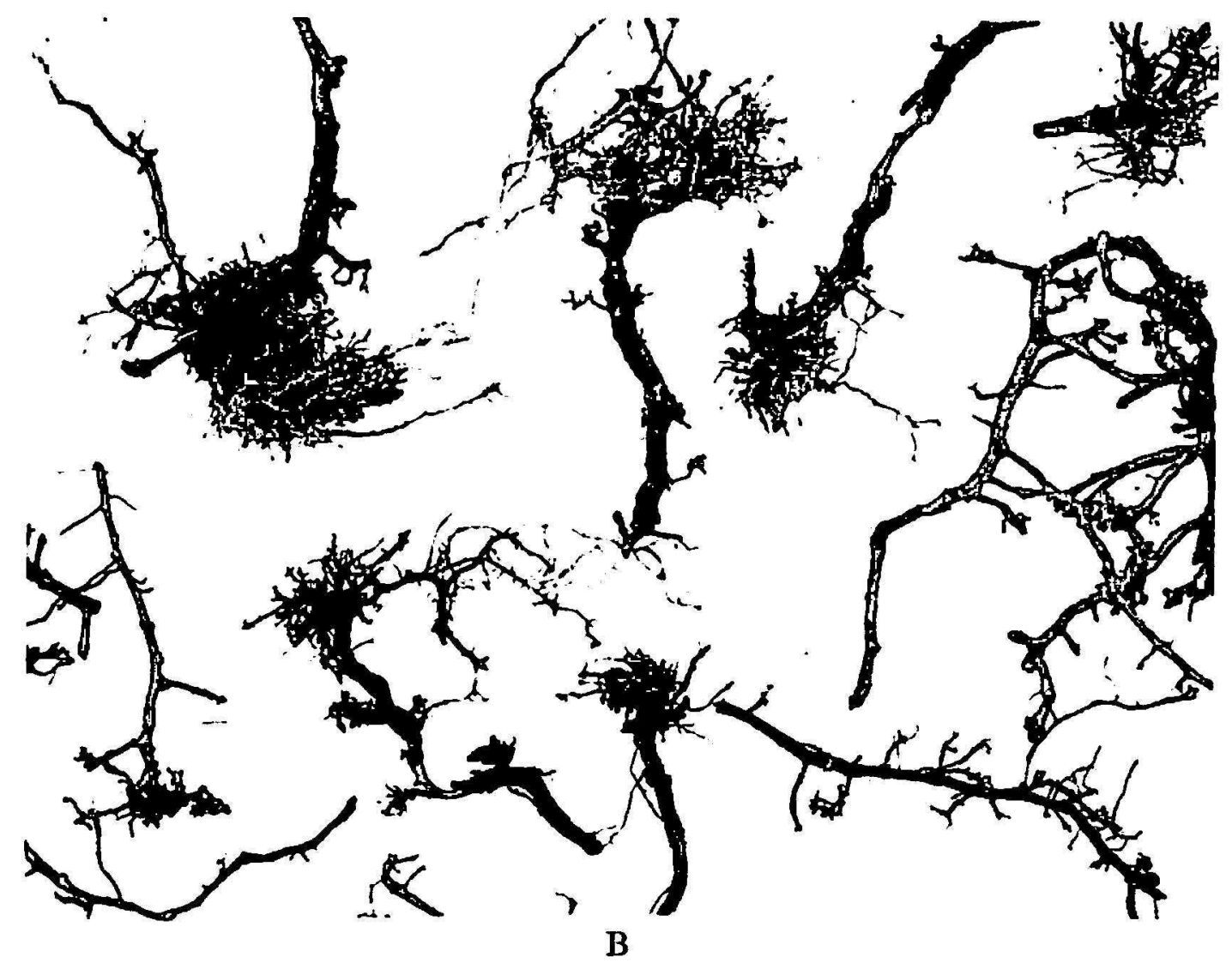

Fig. 2.-A, Pineapple roots showing root-knot galls, the "broomed" condition caused by nematodes, and also rotting. B, Pineapple roots displaying "broomed," galled, and rotting conditions caused by root-knot and ot her nematodes. 

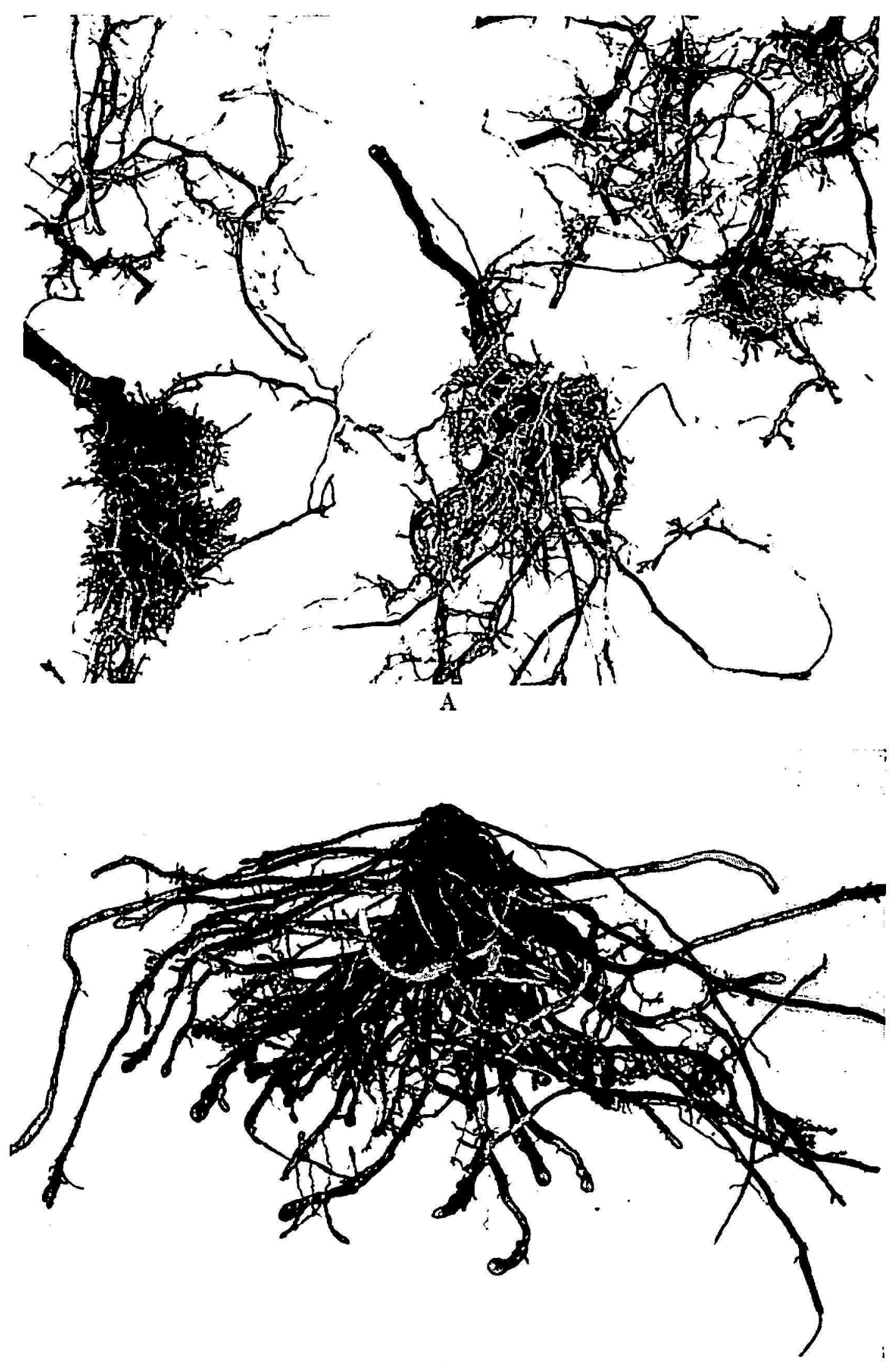

B

FIG. 3.-A, Bull-head pineapple roots from the Southwestern Region displaying a chronic "broomed" condition and also decay of the root cortex caused by the destruction of root 1 ips by nematodes. B, Roots from Red Spanish variety pineapple showing the type of root system found in sandy soils infested with parasitic nema. todes, as well as root galls and "broomed" condition. 

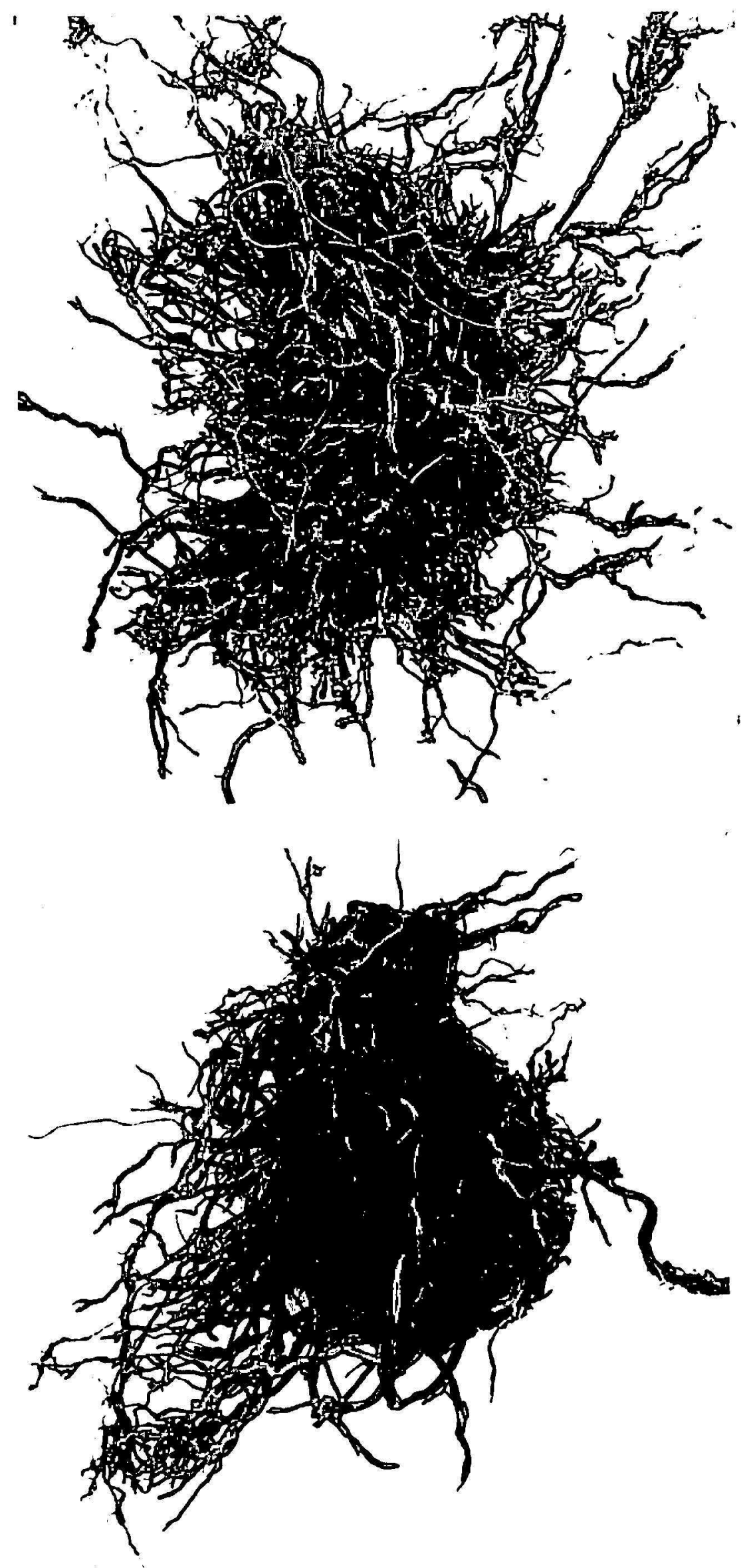

FIti. 4.-A, "Broomed" and rotten condition of pineapple roots common where populations of Helicolylenchus, Rolylenchulus, and P'ralylenchus, are large. B, Typical pineapple root system found growing in the hard-clay soils of the Southwestern Region where parasitic nemat odes of Helirolylenchus, Rolylenchulus, and Pratylenchus were numerous. 
Nematodes have been assumed to weaken the plants by interfering with the regular plant functions and so preparing the way for the invasion of other diseases. No careful study of this sort was conducted.

No reliable estimate of the amount of nematode damage done to pineapple plants on the Island was at hand, but it was estimated that great part cf the crop is lost. This was based on the damage done to the crop as evidenced by reduction in yield and number of shoots preduced, and the control expenses.

\section{DISCUSSION AND CONCLUSIONS}

At least 16 of the 23 different genera recovered from soil and root samples of pineapple plantings in different Regions of Puerto Rico during this study were dangerous plant parasites. Six genera, as shown in table 3 , were sufficiently widespread to be considered major pests in pineapple fields and to be the cause of the decline in pineapple production in Puerto Rico. Rotylenchus, the reniform nematode, and Helicotylenchus, the spiral nematode, were present in great numbers both in roots and in the surrounding soil, which suggests that they are probably the most serious pests. Meloidogyne, the root-knot nematode, Pratylenchus, the meadow or lesion nematode, Ditylenchus, the bulb and stem nematode, and Paratylenchus, the pin nematode, were widely distributed al $\div$, thus adversely affecting pineapple production at least to some extent. These results are in aceordance with those of previous studies.

It has been long known in Hawaii that the root-knot nematode, Meloidogyne spp., is causing considerable damage to sugarcane, $(3,4,7,10,32$, $38,39,40,44,49,50,51,52,53)$ pineapple, and many other agricultural crops. The other five genera are also well-know in relation to nematode decline in pineapples. A species of the meadow nematode, Pratylenchus brachyurus, known at that time as Tylenchus brachyurus, was noted on pineapple roots in Hawaii (16). This species was the most common of the meadow nematodes found in the samples during this study. The reniform nematode, Rotylenchulus reniformis, was reported as being one of the most common nematodes affecting pircapple in Hawaii (35). The pin nematode, Paratylenchus, was found in pineapple roots of Hawaiian plantations by Linford, Oliveira, and Ishii (37). Linford (39) reported "Injurious nematodes. . . , ale already cstablished widely in pineapple fields in the Loma Bonita area, both in lands that were formerly forest and those that were grassy fields." Although Meloidogyme species were considered to be the most destructive, Iinford recognized that species of Pratylenchus were "capable of serious injury to roots when abundant." Rotylenchus also was frequently extracted. Probably most of the specimens of this genus as reported were actually members of Helicotylenchus since, previously, both 
types were included under Rotylenchus. Although these genera were universally distributed we cannot eliminate the possibility that some of the other genera can be equally important as plant parasites in certain pineapple fields. Many of them were found to be associated with the general symptoms of nematode attacks in several locations.

Large populations of parasitic nematode types were observed. A summary of the numbers found is shown in tables 3 and 4 . The average number of nematodes per square meter, 1.75 millions, or 7.05 billions per acre, in the whole Island seems to be high. In previous studies in the United States $(9,11,47)$ it was found that the number of nematodes in the top foot of the soil was as high as thousands of millions, but no special figure was given. Other calculations show 3 billion nematodes as being the average number per arable acre of soil. In a more precise study conducted in Switzerland by Stockly (48), it was shown that there were from 2 to 18 million nematodes per square meter in the top $15 \mathrm{~cm}$. (about 6 inches) of cultivated and pastureland. These figures are higher than ours, although it should be kept in mind that only parasitic nematodes were included in the present study, even though the identifications and calculations were done for free-living and predatory genera found. The dry soils, due to the general drought suffered in the Island, may have had some effect on the occurrence of the nematodes, causing a reduction in populations.

The reniform and the spiral nematodes were the most numerous, followed by Pratylenchus, Ditylenchus, and Paratylenchus. In Hawaii the situation seems to be different because root-knot nematodes are reported the most abundant there. In Puerto Rico the root-knot nematode was found only in the Northern Region and then not in considerable numbers, although it is probably more abundant since only larvae and males were counted without taking into consideration adult females.

Some of the observed ecological factors seemed to exert their influence upon the nematode populations while others showed no apparent relation. Rainfall showed no relationship to population size in gencral, although some effect on root-knot populations was apparent. Since the soil moisture was not taken, we cannot make general conclusions. Soil moisture has been considered a crucial factor in the activity of nematodes, which affects their distribution in the soil. Godfrey (15) recognized humidity as playing an important part in the life cycles of nematodes.

In this study a combination of both temperature and humidity secmed to have more effect than either of the two alone, although some direct effect was noted for high and low temperatures. The number of nematodes was lower (table 6) where temperatures were high and precipitation low. These results appear to support the generalization made by Godfrey (14), Godfrey and Hagan (19), and Godfrey and Hoshino (22). Hagan (27) found 
that, since a temperature of $40^{\circ} \mathrm{C}$. for 2 hours and 15 minutes is lethal to the larvae of the root-knot nematode, it is "quite apparent" that this nematode cannot survive at a $1 / 4$-inch depth in the soil during the greater part of the year. "At a depth of 3 inches during the summer months the temperature of exposed soil approaches this critical point at intervals so that comparatively few, if any, nematodes find a suitable environment above this level at any time". Contrasting opinions have been given as to the role of temperature and moisture. Some authors believe that moisture is not so important since there is always some humidity in the soil; even under conditions of drought nematodes are able to move in the soil. Steiner (45) considered the temperature and moisture together with food availability to be the most important factors conditioning maxima of nematodes in the soil.

The range of $\mathrm{pH}$ of the soils included in this study did not appear to be of any importance in population distributions. This has been a controversial matter, and although it was previously claimed that it has its effect as a selective or conditioning factor for plant nematodes, studies conducted in Hawaii by Godfrey and Hagan (19) with the root-knot nematode, showed that there was no such relationship.

In general, nematode populations were largest in sandy and sandy-loams of the Northern Region but less so in hard clay soils of the Southwestern and Central Regions. This pattern was followed by Rotylenchulus while for Helicotylenchus no difference was noticed. The root-knot nematode was common also in sandy loams although its population numbers were higher in clay soils of the Northern Region. This genus was represented in all samples taken from sandy loam soils while present in only a few of the samples taken from clay soils. This nematode is usually found in light soils, although it can multiply freely in clays once it has been introduced there. Its higher percentage presence in sandy loams can be explained by the fact that its movement here is easier and its transportation from place to place is hastened by many factors.

The variety and the age of the plants and the previous crop planted in the respective fields were conclusive factors conditioning population size, although statistical analysis revealed no significant differences among them. The Smooth Cayenne variety of pineapple was more susceptible to nematode attack than was the Red Spanish variety. No comparison could be made with the Puerto Rico Bull Head since this is cultivated in one Region only, where the other two are absent. It is a known fact that different species and varieties of plants react in different ways to the attack of nematodes, and at the same time different species of nematodes are more attracted by some varieties of plants than by others.

In the fields which were previously cultivated with sugarcane and which 
had been planted to pineapple from 4 to 12 years, the number of nematodes was highest. Next in this regard were pastures. Those fields rotated with Crotalaria species also showed high nematode populations although crotalarias are supposed to be resistant to some nematode species. It should be kept in mind that many weeds which are suitable nematode hosts also grow in these fields, and that those weeds have been growing in pineapple fields for several years. Fields planted with pineapple for 12 to 20 years or more showed the fewest nematodes; this is the opposite of what one usually expects.

Differences were noted in relation to the age of the plants and nematode populations but these were not statisically significant. Plants 18 months old harbored higher nematode populations than did younger or older plants, while populations were lower after 30 months.

Other edaphic and biological factors present in the soil have their effects. Bacteria and protozoa feed upon and cause disease in nematodes. Nematodes are preyed upon by three distinct groups of fungi: The Zoopagales, the nematode-trapping Hyphomycetes, and the endozoic Hyphomycetes (13). Animals such as earthworms, mites, millipedes, and insects also are important, but, although many of them were observed in the samples, no study was conducted and no data on their effects were taken.

Fertilizers and other soil additives are important as conditioning factors, but no study was undertaken. In Arecibo and in Vega Baja where soil fumigation is used for the control of nematodes, and where the plants were apparently healthy, the root systems normal, and the yield high, the higher number of nematodes was found. This may be caused by either of three factors or a combination of them: 1 , The methods employed for the application of chemicals in these places are in some way improper and/or reinfection is hastened by cultivation methods; or 2 , the chemicals kill the nematode enemies at the same time that they reduce the nematode populations. The plants have a good start and grow vigorously. Since the nematodes do not have the same competition of their natural enemies, they multiply rapidly until populations heavier than the ones before fumigation are found. Since the plants are already well-established the heavy populations do not have the effect they could have if early infections occurred. This is the principle usually used for nematode control in perennials where a complete kill of the nematodes is not expected, but fumigation will insure a good start for the plants. Besides this 3, and perhaps more logical, is the fact that the nematodes will be able to reproduce and multiply much quicker when food is available in the form of a well-developed root system such as is present in fumigated fields, at least during the first months after fumigation. So the nematodes in these roots are able to reach higher population numbers than in a weak root system. 
From the results obtained in this study and from scattered greenhouse and field trials it is concluded that plant-parasitic nematodes constitute a major problem in the production of pineapple in Puerto Rico. The genera found are not only widespread but also numerous. Large numbers of parasitic forms are usually associated with dwarfing of plants, chlorosis, occurrence of reddish and black spots on the leaves, narrow leaves, dying back of the leaves, abnormal, malformed, galled, rotten and "broomed" roots, as well as marked reduction in fruit size with the consequent relation instances. A great part of our production is being lost and nematodes may be cited as one of the main causes.

\section{SUMMARY}

In this study undertaken in Puerto Rico during the months from March through September 1957, 60 different samples of plant-parasitic nematodes from roots and soil were taken from various pineapple farms in 3 of the 4 production Regions of Puerto Rico: Northern, Southwestern, and Central. The fields were selected at random, and those showing no symptoms of nematode injury, as well as those showing such symptoms, were studied. The methods employed for field collection were a modification of those used by Cobb. The laboratory methods and the recovery of nematodes from the soil were a combination of the screen and Baermann-funnel methods.

Twenty-three different genera of nematodes were recovered, 16 of which were recognized as being plant parasites and the other 7 were suspected. There was no case in which a sample was found to be free of plant nematodes. In fact, the lowest number of genera present in 1 sample was 5 and the highest was 15 , with a mean average of 9 genera per sample.

The most frequently occurring genera were Rotylenchulus and Helicotylenchus which were present in all the samples. Less frequent but still common were Pratylenchus, Paratylenchus, Aphelenchoides, Dorylaimus, Ditylenchus, and Meloidogyne. This last one was found only in the Northern Region. The other 16 genera were less widely distributed.

Populations of the first 2 genera were large, with a general mean average of 0.97 and 0.67 million per square meter ( 3.90 and 2.70 billions per acre), respectively. Their population size was higher in the Northern Region, while in the Central and Southwestern Regions it was lower. The average nematode population was 1.75 millions per square meter $(7.05$ billions per acre) at 6 inches depth. Several edaphic, climatological, and biological factors were found to be related to population sizes for all the genera and some specific genera studied. Population size of the genera varied with geographic location, type of soil, age and variety of the plants (although not statistically), previous crops planted, and temperature. No apparent 
relation was noted between precipitation except for the root-knot nematode and $\mathrm{pH}$ of the soil and nematode population size. No study was conducted of other biological factors such as different soil organisms, or cultivation methods and soil additives.

It was estimated from the results obtained in this study and the damage observed in the pineapple plantings of this as well as previously scattered experiments that nematodes cause the loss of a great part of the crop yield in the Island. This loss has been calculated by the Extension Service officers to amount to at least 40 percent of the potential yield.

\section{RESUMEN}

En este trabajo, efectuado en Puerto Rico durante los meses que se extienden de marzo a septiembre de 1957, se ofrecen los resultados obtenidos del estudio de 60 muestras distintas de raíces y suelos de varias siembras de piña, en tres de las cuatro áreas productoras de esta fruta que alojaban nemátodos fito-parasíticos. Los piñales fueron seleccionados al azar, sometiendo a estudio tanto los que no presentaban evidencia alguna de infestación de nemátodos, como los que mostraban efectos de indudable infestación.

En la colección de estas anguílulas se emplé el método originalmente usado por Cobb, con algunas modificaciones. También una combinación de los métodos de cedazos y embudos de Baermann para separarlos de la tierra y las raices.

Se obtuvieron 23 géneros distintos de nemátodos, 16 de los cuales eran parásitos de plantas, y los otros 7 eran meramente sospechosos. No hubo un solo caso de siembras de piña que estuviera libre de la acción de nemátodos. El menor número de géneros encontrados en una muestra fué $5, \mathrm{y}$ la infestación mas alta 15, lo cual arroja un promedio de 9 géneros de estas anguílulas por muestra. Estos géneros estaban representados por innumerables especies.

Los géneros de nemátodos que con más frecuencia encontramos fue el Rotylenchulus y el Helicotylenchus, presentes ambos en todas las muestras recogidas. Menos frecuentes, pero muy comunes, se observaron especies de Pratylenchus, Paratylenchus, A phelenchoides, Dorylaimus, Ditylenchus y Meloidogyne. Estc último se encontró solamente en muestras tomadas en la costa norte. Los 16 restantes estaban distribuídos en un área menos amplia.

La población de los 2 primeros era inmensa, con un promedio de $0.97 \mathrm{y}$ 0.67 millones por metro cuadrado: 3.90 y 2.70 billones por acre, respectivamente. Liran más numerosos en la costa norte, y su incidencia menor en las regiones del centro y suroeste. La población promedio de nemátodos fue de 1.75 millón por metro cuadrado (7.05 billones por acre) a $15-20 \mathrm{~cm}$. (6 
pulgadas de profundidad). Varios factores edáficos, climatológicos y biológicos concurrieron para determinar el tamaño poblacional de todos los géneros y de algunos que, específicamente, se estudiaron.

El tamaño de la población de nemátodos varió, (aungue no estadísticamente) según la localización geográfica, el tipo de suelo, edad y variedad de plantas, siembras anteriores y temperatura.

No hubo evidencia de relación alguna entre humedad en términos de precipitación (con excepción del nemátodo que causa nudos en la raíz de las plantas (Meloidogyne spp.), entre el $\mathrm{pH}$ del suelo y el tamaño de la población de estos organismos. No se realizaron estudios sobre la relación del desarrollo de los nemátodos con otros factores de orden biológico, otros organismos del suelo, métodos de cultivo y enmiendas al terreno.

De los resultados obtenidos en este estudio, de los daños observados en distintas áreas de piñales, así como de diversos experimentos efectuados anteriormente, se llega a la conclusión de que una gran parte de la cosecha de esta fruta se está perdiendo actualmente en Puerto Rico, debido sin duda a la dañina acción de los nemátodos. Funcionaios del Servicio de Extensión Agrícola calculan que esta pérdida asciende a un 40 por ciento de la producción.

\section{LITERATURE CITED}

1. Alvarez, L. A., and López-Matos, L., Influence of root-knot nematodes on the decline in vigor of the Red Spanish variety of pineapples in Puerto Rico, $J$. Agr. Univ. P.R., 38 (1) 61-72, 1954.

2. Buhrer, E. M., Common names of some important plant pathogenic nematodes, Plani Dis. Rep., 38 (8) 535-41, 1954.

3. Cassidy, G. H., Nematodes associated with sugarcane in Hawaii, Hawaiian Planlers Rec. 34 (4) 379-87, 1930.

4. Cassidy, G. H., and Zwaluwenburg, R. H., Nematodes in Relation to Growth Failure of Sugarcane in Hawaii, Report Association of the Hawaiian Sugarcane Technologists $610-5,1927$.

5. Chitwood, B. G., and Chitwood, M. B., An Introduction to Nematology, Monumental Printing Co., Baltimore, Md., 2-3, 1950.

6. Christie, J. R., and Perry, V. G., Removing nematodes from the soil, Proc. Helminth. Soc. Washington, 18 (2) 106-8, 1951.

7. Cobb, N. A., Fungus Maladies of the Sugarcane with Notes on Associated Insects and Nematodes, Hawaiian Sugar Planters Assoc. Div. Pathol. and Physiol., Bul. 5 (254) pp. 6, 1906.

8. - Fungus maladies of the sugar cane, Hawaiian Sugar Planters Assoc. Div. Pathol. and Physiol, Bul. 6, 1-110, figs. 1-66, pl. 1-7, 1909.

9. - Nematodes and Their Relationships, Yearbook of the Department of Agriculture, Soils, Washington, D.C., 457-90, 1914.

10. - Tylenchus similis, the cause of a root disease of sugarcane and banana, J. Agr. Res., 4 (6) 561-8, 1915.

11. - Estimating the Nema Population of Soil, USDA, Bureau of Plant Indust ry, Agricultural Technology Circular 1, Washington, D.C., 3-48, 1918. 
12. Dieter, C.E., Techniques for Collecting and Isolating Plant Parasitic Nematodes, Down to Earth, (Bul. from Dow Chemical Co.) 10 (2) 8-11, 1954.

13. Duddington, C. W., Inter-relations Between Soil Microflora and Soil Nematodes, Soil Zoology, Academic Press, Inc., New York, N.Y. 284-301, 1955.

14. Godfrey, G. H., The effect of temperature and moisture on nematode root-knot, J. Agr. Res. 33 (3) 223-54, 1926.

15. - Legumes as Rotation and Trap Crops for Nematode Control in Pineapple Fields, Exp. Sta. of the Assoc. of Hawaiian Pineapple Canners, Univ. of Hawaii, Bul. No. 10, 1-21, 1928.

16. - A destructive root disease of pineapples and other plants due to Tylenchus brachyurus, n. sp. Phytopath., 29 (7) 611-29, 1929.

17. - Indicator plants for measuring soil populations of the root-knot nematode, Heterodera marioni (Cornu) Goodey, Soil Sci., 38 3-27, 1934.

18. - The pineapple root system as affected by the root-knot nematode, Phylopath., 26 (5) 408-28, 1936.

19. Godfrey, G. H., and Hagan, H. R., Influence of soil hydrogen-ion concentration on infections by Heterodera radicicola (Greef) Muller, Soil Sci. 35 (3) 175-84, 1933.

20. - $\longrightarrow$ and - A study of the root-knot nematode trap crop under field soil conditions, Phytopath., 24, 648-58, 1934.

21. - , and - Some measurements of detrimental effects of the root-knot nematode on the pineapple plant, Phytopalh., 27 (4) 515-30, 1937.

22. Godfrey, G. H., and Hoshino, H. M., Studies of certain environmental relations of the root-knot nematodes, Heterodera radicicola, Phytopath., 23 (1), 1933.

23. - , and - The trap crop as a means of reducing root-knot nematode infestation, Phytopath., 24 635-53, 1934.

24. Godfrey, G. H., and Morita, H. T., Effects of some environmental factors on the root nematode, Phytopath., $1983-4,1929$.

25. Godfrey, G. H., Oliveira, J. M., and Gittel, E. B. H., The duration of life of the root-knot nematode, Heterodera radicicola in soils subjected to drying, Soil Sci., 36 (3) 185-95, 1933.

26. Goodey, T., Soil and Freshwater Nematodes: A Monograph, John Wiley and Sons, Inc., New York, N.Y., 1-390, 1951.

27. Hagan, H. R., Hawaiian pineapple field soil temperatures in relation to the nematode, Heterodera radicicola (Greef) Muller, Soil Sci., 26 (2) 83-95, 1933.

28. Hagan, H. R., and Collins, J. L., Studies on varietal resistance of pineapple plants, Part II, Plant Resistance to Heterodera marioni (Cornu) Goodey, J. Hered., 26 (1) 35-46, 1932.

29. Hoshino, H. M., and Godfrey, G. H., Thermal death point of Heterodera radicicola in relation to time, Phytopath., 23 260-70, 33.

30. Informe Anual, Año Fiscal, Control de la Degeneración en la Piña, Univ. P.R., Agr. Exp. Sta., Río Piedras, P.R., 1952-53.

31. Informe Anual, Año Fiscal, El Resurgimiento de la Industria de la Piña, Univ. P.R., Agr. Exp. Sta., Río Piedras, P.R., 1953-54.

32. Jensen, H. J., et al., Nematodes associated with varietal yield decline of sugarcane in Hawaii, Plant Dis. Rep. 43 (2) 253-60, 1959.

33. Linford, M. B., Stimulated activity of natural enemies of nematodes, Sci., 85 (2196) $123-4,1937$.

34. - Pineapple Diseases and Pests in Mexico, Plant Protection Bul. 1 (2) 21-5, 1952. 
35. Linford, M. B., and Oliveira, J. M., Rolylenchulus reniformis, new genus, and species, a nematode parasite of roots, Proc. Helminth. Soc. Washington, 7 (1) 35-42, 1940.

36. Linford, M. B., and Yap, F., Some host plants of the reniform nematode in Hawaii, Proc. Helminth. Soc. Washington, 7 (1) 42-4, 1940.

37. Linford, M. B., Oliveira, J. M., and Ishii, K., Paratylenchus minulus n. sp., a nematode parasite on roots, Pacific Science, 3 (2) 111-9, 1949.

38. Martin, J. P., Sugarcane Diseases in Hawaii, Honolulu, Hawaii, 1-295, 1938.

39. Muir, Frederick, Nematodes considered in relation to root rot of sugarcane in Hawaii, Rep. Hawaiian Sugar Tech., 5th Ann. Mtg. 14-8, 1926.

40. Muir, Frederick, and Henderson, Gertrude, Nematodes in connection with sugarcane root rot in the Hawaiian Islands, Hawaiian Plant Rec. 30 233-50, 1926.

41. Pennock, W., La piña (Puerto Rico) Unión Panamericana, Oficina de Cooperación Agrícola, Pub. Agr. Nos. 134 and 135, 1940.

42. Pérez, M. E., Pineapple Gummosis in Puerto Rico and its Control, Univ. P.R., Agr. Exp. Sta., Río Piedras, P.R., Technical Paper 21 pp. 1-71, 1957.

43. Steiner, G., Plant Nematology Research in the Bureau of Plant Industry, Soils, and Agricultural Engineering, Plant Disease Rep. Supl. 195, 1950.

44. - The soil in its relationship to plant nematodes, Soil Sci. Soc. Fla. Proc. 12 24-9, 1952.

45. Stewart, Guy R., and Hanson, Fred, The effect of nematodes upon cane roots in sterilized soil, Hawaiian Planters Rec. 32 (2) 217-23, 1928.

46. Tarjan, A. C., A new genus, Pseudohalenchus (Tylenchida: Nematoda) with descriptions of two new species, Proc. Helminth. Soc. Washington, 25 (1) 20-5, 1958.

47. Taylor, A. L., The Tiny but Destructive Nematodes, USDA Yearbook of Agriculture, Soils, Washington, D.C., 78-82, 1953.

48. Timm, R. W., The study of free-living nematodes, Turlox News, 31 (9) 170-1, 1953.

49. Wizmer, C. A., Reduction in Yields by Nematodes Feeding on Cane Roots, Monthly Rept., Exp. Sta. Hawaiian Sugar Planters Assn. 2, 1957.

50. Zwaluwenburg, R. H. van, The Nematodes Attacking Cane Roots in Hawaii, in Williams, F. X., Handbook of the insects and other invertebrates of Hawaiian sugar cane fields, Honolulu, Hawaii, 352-68, 1931.

51. - The soil fauna of Hawaiian cane fields, Hawaiian Planters Rec. 30 250-5, 1926.

52. - - Summary of investigations of the soil fauna of sugarcane fields in Hawaii, Int. Soc. Sugar Cane Tech. 3rd, Cong. (1929) 216-25, 1930.

53. - - The nematodes attacking cane roots in Hawaii, Int. Soc. Sugar Cane Tech. Proc. 4th, Cong., Bul. 5, 1932. 